\title{
Az Európai Újraélesztési Társaság (ERC) 2021. évi speciális esetekben és helyzetekben végzett újraélesztésröl szóló ajánlásának összefoglaló bemutatása
}

\author{
Schiszler Bence, Priskin Gábor, \\ Pécsi Tudományegyetem Egészségtudományi Kar, Sürgősségi Ellátási és Egészségpedagógiai Intézet, \\ Oxyológiai, Sürgősségi Ellátási Tanszék \\ Pandur Attila, Tóth Balázs, \\ Pécsi Tudományegyetem Egészségtudományi Kar, Sürgősségi Ellátási és Egészségpedagógiai Intézet, \\ Oxyológiai, Sürgősségi Ellátási Tanszék, Pécsi Tudományegyetem Egészségtudományi Doktori Iskola \\ Prof. Dr. Betlehem József, \\ Pécsi Tudományegyetem Egészségtudományi Kar, Sürgősségi Ellátási és Egészségpedagógiai Intézet \\ Dr. Radnai Balázs, \\ Pécsi Tudományegyetem Egészségtudományi Kar, Sürgősségi Ellátási és Egészségpedagógiai Intézet, \\ Oxyológiai, Sürgősségi Ellátási Tanszék
}

\section{Thrombembóliás eredetü keringésmegállások}

Az akut tüdőembólia egy súlyos, sokszor az életet közvetlenül veszélyeztető kórfolyamat, ezért időbeni diagnózisa és megfelelö terápiája életmentő lehet. A keringésmegállás elkerülése érdekében javasolt az ABCDE megközelítés használata. Amennyiben a klinikai rizikóstratifikációs pontrendszerek (Wellsscore, módosított Genfi-score) alapján felmerül a pulmonalis embólia lehetősége, magas időfaktorú kórfolyamatként a sürgősségi ellátásban első feladatunk e kórfolyamat kizárása. Amennyiben ez nem lehetséges, eszerint kell a beteg ellátását késlekedés nélkül megkezdeni. A kórfolyamatok kizárásának klinikai eszközei a magas negatív prediktív értékủ vizsgálatok. Haemodinamikailag stabil beteg esetén a kórfolyamat kizárása az elsődleges cél, melynek hatékony eszközei a klinikai rizikóstratifikáció valamint a D-dimer vizsgálatok, így ezek alkalmazásával kezdjük a diagnosztikát. Amennyiben haemodinamikai instabilitás jeleit észleljük, a beteg sokkos vagy hipotenzív, mihamarabbi CT angiográfia elvégzése javasolt. Egyéb diagnosztikus módszereket, amennyiben elérhetőek, stabil állapotú betegek esetében, jobb kamrai túlterhelés echokardiográfiás bizonyítékának birtokában végzünk.
A tüdőembólia súlyosságának és prognosztikai megítéléséhez, továbbá a terápia kockázat/haszon arányának mérlegeléséhez nyúlt támpontot a pulmonális embólia súlyossági index (PESI, SPESI) meghatározása.

ABCDE szemlélet szerinti megközelítés:

A- súlyos hypoxia jeleit mielőbb ismerjük fel és kezdjük el kezelni.

B- Hirtelen kezdetű nehézlégzés progressziója -tüdőbetegség, PTX, anaphylaxia fennállása nélkülesetekben magas áramlással kezdjünk oxigén terápiát.

C- Készítsünk 12 elvezetéses EKG-t, ACS kizárására, figyeljük meg a kamrai strain jeleket. Ismerjük fel a hemodinamikai instabilitást, azonosítsuk be a magas rizikójú betegeket.

Használjunk ágy melletti echocardiográfiát.

Kontraindikáció hiányában a diagnosztikai algoritmus közben adjunk heparint $80 \mathrm{NE} / \mathrm{ttkg}$ dózisban. A diagnózis erősítése céljából használjunk CT pulmonális angiográfiát (CTPA)-t. 
Multidiszciplináris teamek felállítása a magas rizikójú betegek menedzselésére.

Kezdjünk thrombolysist gyorsan progrediáló betegek esetén, alternatív megoldásként sebészi embolektómia, vagy perkután katétervezérelt beavatkozás végzése merülhet fel.

E- SAMPLE séma alkalmazásával vegyünk fel részletes anamnézist a korábbi betegségekre, vénás thrombembóliás eseményekre ( $\mathrm{PE}$ vagy MVT), rizikótényezőkre (immobilizáció, sebészeti beavatkozás az elmúlt időszakban, daganatos megbetegedés, DVT klinikai jelei, OAC, hormonterápia, repülős utazás), szedett gyógyszerekre.

Keringésmegállás esetén a leggyakrabban megjelenő iniciális ritmus a pulzus nélküli elektromos aktivitás (PEA). Jó minőségű CPR esetén is tartósan alacsony kilégzés végi $\mathrm{CO}_{2}$ esetén merüljön fel pulmonális embólia. Diagnosztikai eszközként alkalmazzunk sürgősségi echokardiográfiát. Amennyiben a keringésmegállás hátterében PE valószínűsíthető, kezdjünk thrombolitikus terápiát, ebben az esetben a CPR- $t$ 60-90 percig folytassuk.

\subsection{Koronária thrombosis}

Fontos a megelőzés, az akut kardiovaszkuláris események számának csökkentése. A betegedukáció segítségével csökkenthető az első orvosi kontaktus ideje. A laikusokat, mint a túlélési lánc fontos szereplöit, támogassuk a BLS-ben.

Azonosítsuk be a STEMI elváltozást a beteg panaszai és vitális paraméterei, EKG elváltozások alapján.

Spontán keringés visszatérése után, STEMI esetén PCI választandó, amennyiben a teljes ischaemiás idő nem haladja meg a 120 percet. 120 percen túli idő esetén prehospitális thrombolysis megkezdése preferálandó PCI centrum felé történő szállítás közben.

NSTEMI esetén mérlegeljük a keringésmegállás okát, a beteg anamnesztikus adatait, valamint az EKG elváltozásokat. Koronária thrombosis gyanúja esetén a teendőket és a döntéstámogató lehetőségeket az alábbi ábrán foglaltuk össze. (1. ábra)

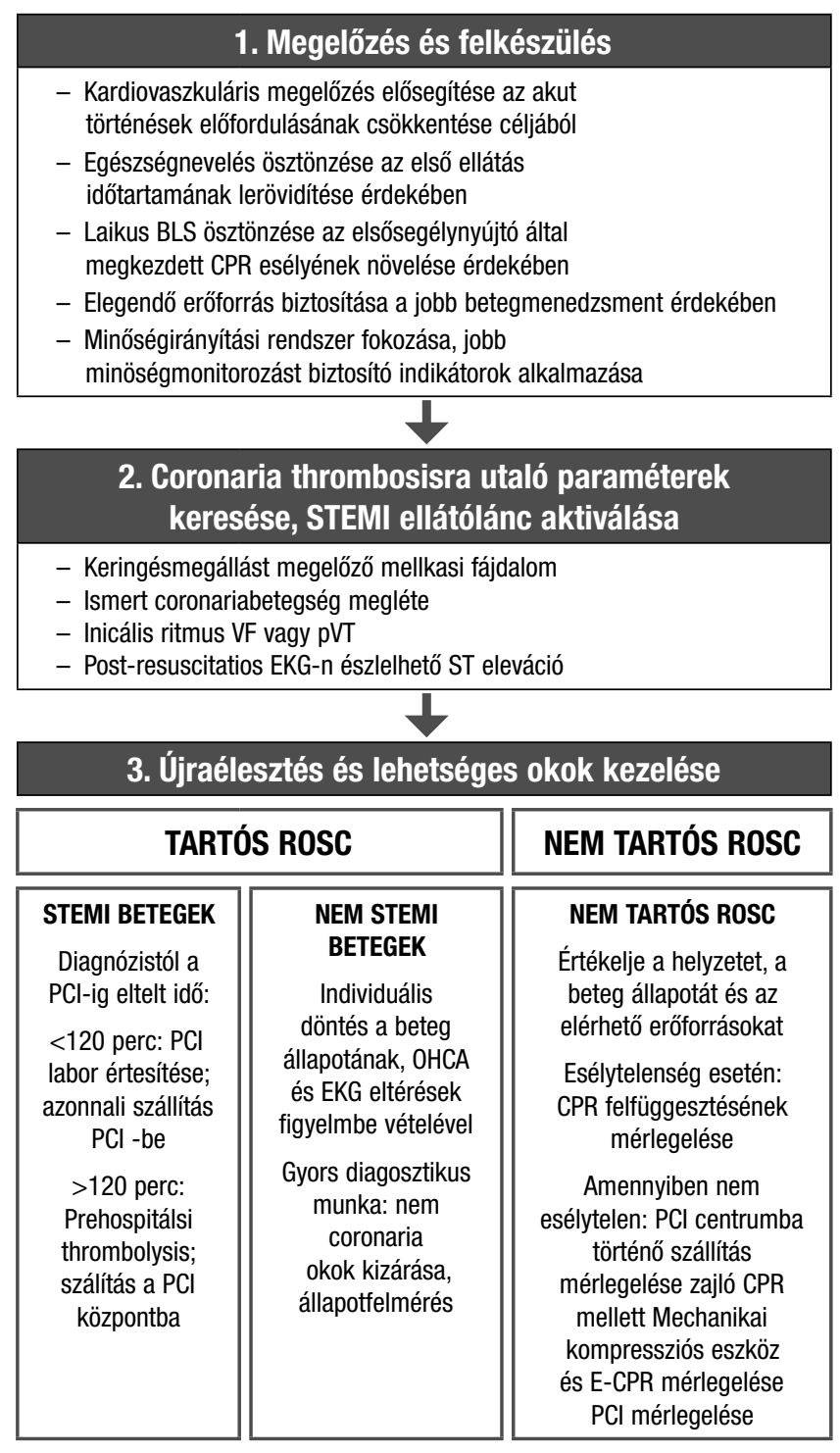

1. ábra: A coronaria thrombosis algoritmusa. (1)

\section{Traumás eredetű keringésmegállás}

A traumás eredetű keringésmegállás (TCA) magas mortalitású kórok, a túlélés tekintetében 1,6\%-32\% közötti arányokról lehet beszámolni, ugyanakkor trauma következtében bekövetkezett keringésmegállás szempontjából ROSC-ot követően jobb neurológiai kimenetellel lehet számolni egyéb okú keringésmegálláshoz képest. A reverzibilis okok tekintetében 48\%-ban kontrollálhatatlan vérzés, 19\%-ban tenziós pneumotorax (tPTX), 13\%-ban asphyxia, 10\%-ban pedig perikardiális tamponád jelölhető meg az arreszt állapotért felelös kórokként. A CPR megkezdésekor tapasztalt iniciális ritmus esetén elmondható, hogy TCA-ban 66\%-ban pulzus nélküli elektromos aktivitás (PEA), 30\%-ban 
asystolia, és 6\%-ban kamrafibrilláció (VF) volt megfigyelhető. A sikeres újraélesztés eléréséhez a reverzibilis okok eredményes felismerése céljából TCA esetén a „bed side” ultrahangok alkalmazása felértékelődik.(2)

Prognosztika tekintetében nincsenek egyértelmű bizonyítékok arra vonatkozóan, hogy TCA esetén melyek azok a faktorok, melyek a túlélést növelik (3), ugyanakkor kutatások rávilágítottak arra, hogy a keringésmegállástól számított rövid időn belül megkezdett CPR, rövid prehoptitális idő, áthatoló mellkassérülés, illetve iniciális sokkolandó ritmus esetén pozitívabb kimenetelről lehet beszámolni. (4) Gyermekek tekintetében viszont ezen faktoroktól függetlenül pozitívabb kimenetelről beszélhetünk a felnőttekhez képest. (5)

Publikációnk e fejezetének célja, hogy a témán belül összefoglalja az ajánlás(1) szerint megfogalmazott sarokpontokat, úgy mint: hatékony mellkaskompresszió, hipovolémia elkerülése/kezelése, hipoxia elkerülése/kezelése, tPTX felismerése és kezelése, kardiális tamponád felismerése és kezelése.

Hasonlóan a többi ERC ajánláshoz, az eredményes TCA ellátáshoz egy 5 pontól álló, „kulcsüzenetként” használható összegzést fogalmaz meg a 2021. évi protokoll, ami a következőket foglalja magába:

1. Ellenőrizzük

- A helyszín biztonságát

- A beteg állapotát, mely ABCDE szerint történő betegvizsgálattal valósul meg

2. Kezelés

- Kövessük az ALS algoritmust

- Minimalizáljuk helyszíni ellátási időt

- Megfelelően oxigenizáljuk a beteget

- Használjuk ki az erőforrásainkat

3. Priorizáljunk

- Reverzibilis okok keresése, megoldása

- $4 \mathrm{H}$

- $4 \mathrm{~T}$

4. Sztenderd ALS algoritmus módosítása az alábbi tényezők által indokoltak szerint:

- Speciális kórokok

- Speciális körülmények

- Speciális betegpopuláció

5. Ajánlott megfontolni

- Korai transzport megkezdése

- ECPR

\subsection{Az újraélesztés meg nem kezdése/ felfüggesztése TCA esetén}

Az guideline egyértelműsíti azokat az eseteket, amikor az ellátó eltekinthet a CPR megkezdésétől, illetve megfogalmazza azokat az eshetőségeket, amikor megfontolható a CPR felfüggesztése, befejezése.

Abban az esetben, amennyiben az ellátó nem tapasztal életjelenségeket a sérültnél, és az anamnesztikus adatokból kiderül, hogy legalább 15 perc telt el a keringésmegállás óta, ami alatt nem történ sem laikus, sem szakember által végzett $C P R$, úgy megfontolható az újraélesztés meg nem kezdése. Hasonló eljárást javasol a protokoll abban az esetben is, ha a sérültnél élettel össze nem egyeztethető sérülések tapasztalhatók.

Amennyiben megkezdődött a CPR, úgy megfontolható annak felfüggesztése, amennyiben minden reverzibilis okot felismert és kezelt az ellátó, de továbbra sem érhető el ROSC, illetve abban az esetben, ha a reverzibilis okok kezelését követően ultrahanggal bizonyítottan nem tapasztalható kardiális aktivitás.

\subsection{Ne nyomjunk ,üres” szívet!}

$\mathrm{Ha}$ a keringésmegállás hátterében hipovolémia, cardiális tamponád, vagy tenziós PTX áll, úgy a mellkaskompressziók bizonyítottan hatástalanabbak, mint ezen kórokok hiányában, és a spontán keringés visszatérésének esélye is jelentős mértékben csökken. (4) Ezen okokból kifolyólag TCA-ban a mellkaskompressziók prioritása csökken a reverzibilis okok megoldásához képest, ugyanakkor azok feltárása és kezelése nem késleltetheti a megfelelő mellkaskompresszió megkezdését. Retrospektíven végzett kohorsz vizsgálat eredményei rávilágítottak arra, hogy traumás eredetű intrahospitális kardiális arresszt (IHCA) esetén bizonyos helyzetekben a nyitott mellkaskompressziók hatásosabbak a zárt mellkaskompresszióknál. (6)

\subsection{Hipovolémia}

TCA esetén fontos, hogy elkerüljük a súlyos hipovolémiás shock kialakulását, vagy a már kialakult sokkot effektíven kezelni tudjuk. A cél, hogy mielőbb adekvát vérzéscsillapítást kezdjünk meg, mivel az nagymértékben hozzájárul a beteg túléléséhez. (7) A protokoll megjegyzi, hogy hipovolémiás sokk esetén 
amint lehetőség van rá, szükséges megkezdeni a vérkészítmények adását. Prehospitálisan alkalmazott transzfúzió abban az esetben kezdhető meg, ha a definitív ellátóhelyre a transzport 20 percél nem tart tovább. (8)

Abban az esetben, ha betegnél kontrolálható vérzést tapasztal az ellátó, úgy azonnal csillapítania kell azt direkt/indirekt nyomással, nyomókötéssel, tournique-vel, illetve egyéb lokális vérzéscsillapító eszközökkel. Kontrollálhatatlan vérzés esetén, annak nehezebb detektálhatósága miatt azonnali medenceöv felhelyezése, húzósínek használata, vérkészítmények, bólusfolyadékok, tramexánsav alkalmazása javasolt. A fent említett beavatkozások ellenére is fennálló, az életet potenciálisan veszélyeztető kontrollálhatatlan vérzés esetén, szigorú feltételek teljesülése mellett megfontolandó az aorta proximális szakaszának kompressziója, sebészi vérzéscsillapító módszer segítségével. Erre opcionálisan a protokoll a resuscitativ thoracotomia-t (RT), illetve a Resuscitative Endovascular Ballon Occlusion- $t$ (REBOA) említi meg.

Neurogén sokk esetén az ajánlás egyértelműen javasolja a vazopresszorok alkalmazását.

\subsection{Hipoxia}

TCA esetén hipoxaemia kialakulásáért lehet felelős akár következményes légúti obstrukció kialakulása, traumás asphyxia, vagy agysérülés következtében kialakult apnoe. A megfelelő légútbiztosítás és lélegeztetési stratégia elengedhetetlen annak érdekében, hogy kivédjük vagy visszafordítsuk a hipoxia következtében kialakult arreszt állapotot. Szükség van a beteg lélegeztetésének folyamatos monitorozására kapnográf segítségével, törekedve a normokapniára. $\mathrm{A} \mathrm{SpO}_{2}$ célértéke legyen $94-98 \%$.

\subsection{Tenziós pneumotorax (tPTX)}

TCA-ban tPTX észlelése esetén mielőbb el kell végezni a betegnél a kétoldali toracostomiát a biztonsági háromszög beazonosítása mellett a 4. interkosztális térben. A protokoll alternatívaként jegyzi meg a tü thoracostomia alkalmazását, a pozitív nyomású lélegeztetés esetében azonban az elözetesen elvégzett thoracostomia hatásosabbnak bizonyult, mint a tü detenzionálás, és kivitelezhetőségében gyorsabb, mint a mellkascsövezés.

\subsection{Kardiális tamponád}

A traumás eredetű kardiális tamponád kialakulásáért leggyakrabban áthatoló mellkassérülés felelös. Ha biztosan beazonosította az ellátó ezt a potenciálisan reverzibilis okot, úgy a protokoll által megfogalmazott szigorú feltételek teljesülése esetén megkezdhető a resuscitatív thoracotomia elvégzése. A feltételek úgynevezett „4 E” maradéktalan létrejötte esetén teljesülnek.

- Előzetes gyakorlat („Expertise”): szükséges a megfelelő kompetenciaszint megléte a beavatkozás elvégzése tekintetében.

- Eszközök („Equipment”): szükséges a beavatkozás elvégzéséhez szükséges eszközök hiánytalan rendelkezésre állása.

- Elvégzéshez megfelelő környezet („Environment”): szükséges a beavatkozás elvégzéséhez alkalmas helyszín kiválasztása.

- Eltelt idő („Elapsed time”): A keringésmegállás és a beavatkozás megkezdése közt eltelt idő nem lehet több 15 percnél.

Abban az esetben, ha mind a 4 E-ben megfogalmazott feltételek teljesülnek, úgy megfontolható a RT elvégzése. Ellenkező esetben alkalmazása kontraindikált.

\section{7 Összegzés}

Összességében elmondható, hogy a 2015-ben megjelent ERC ajánláshoz képest a jelenlegi protokoll kiegészítéseket tartalmaz a TCA tekintetében, ugyanakkor abban az esetben, ha a betegnél kontrollálhatatlan vérzést tapasztal az ellátó, úgy a protokoll az eddigi RT mellett a REBOA alkalmazását javasolja, ha teljes mértékben teljesülnek a „4 E” feltételei. A 2015. évi TCA guidelinehoz képest változás, hogy az ezek között megjelenő eltelt idő („Elapsed time”) 10 percről 15 percre emelkedett. A protokollt összefoglalását az 1. ábra mutatja be.

\section{Hypothermiás beteg ellátása}

Baleseti hypothermiáról beszélünk, ha a beteg maghőmérséklete $35^{\circ} \mathrm{C}$ alá csökken. Súlyos hypothermia esetén az életfunkciók romlása következik be, ami a súlyosságtól függően, tartós kezeletlenség esetén keringésmegállás kialakulását eredményezheti. A spontán keringéssel rendelkező hypothermiás betegek azonnali 


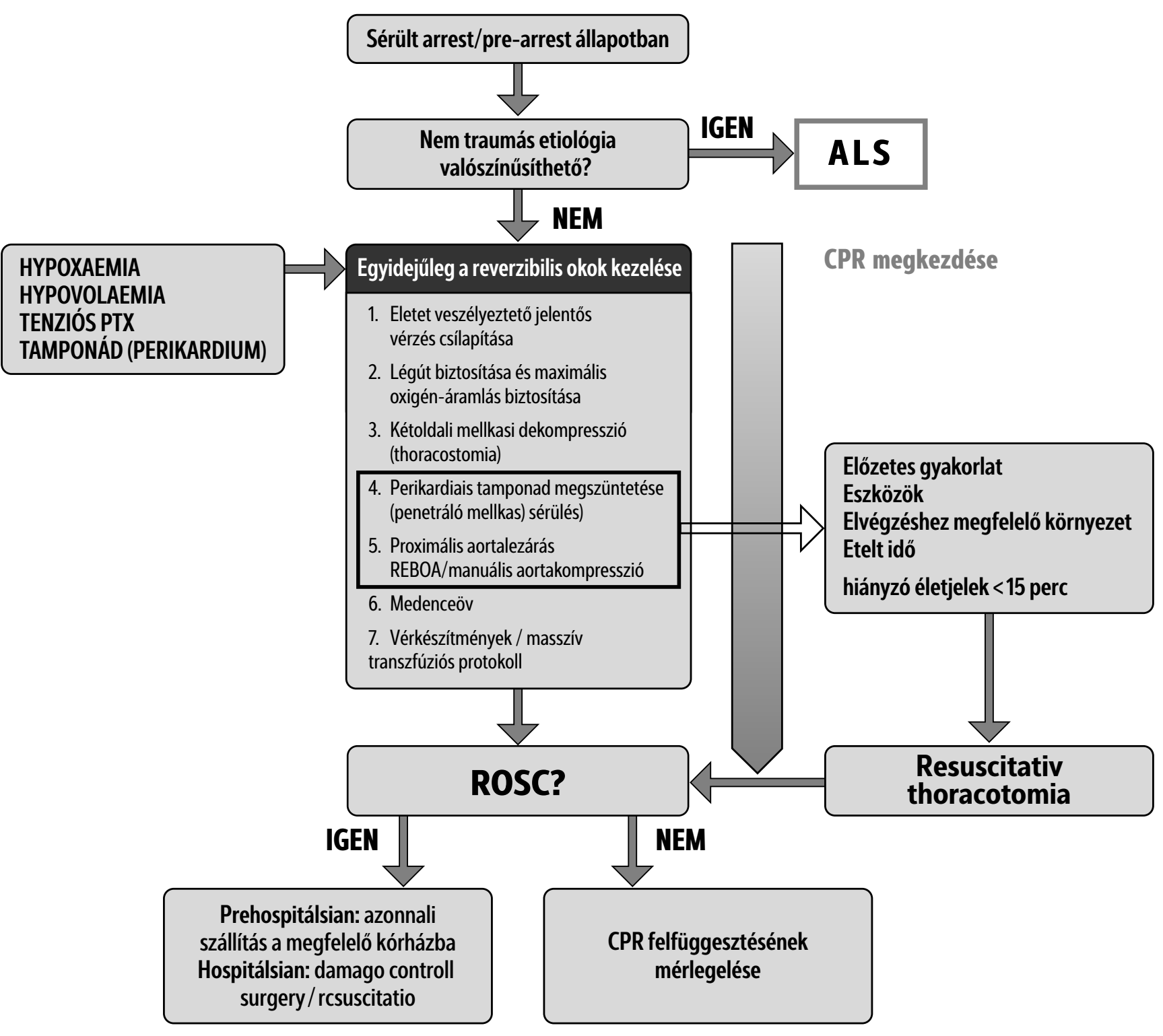

2. ábra: TCA algoritmus(1)

melegítése, és megfelelő gyógyintézetbe történő szállítása elengedhetetlen ahhoz, hogy prognosztika szempontjából a legjobb életkilátásokat lehessen elérni. Arreszt állapotban lévő hypotherm beteg megszakított kardiopulmonális reszuszcitációja (CPR) illetve extracorporális cardiopulmonális resucitációja (eCPR) esetén, a rövid ideig fennálló „no-flow”, illetve „lowflow" idő ellenére is jó neurológiai kimenetellel lehet számolni. (9) (10)

Kiváltó okok alapján meg tudunk különböztetni elsődleges, és másodlagos hypothermiát. Elsődleges kihűlés esetén a külső hőmérséklet jelölhető meg okként, ami minden korosztály számára, alapbetegségtől függetlenül arreszt állapotig juttathatja a beteget.
Másodlagos hypothermia kialakulása figyelhető meg idős, komorbid betegek esetén akár beltéri helyszínek esetén, melyhez nem szükséges a külső hőmérséklet drasztikus csökkenése. (11)

Az ABCDE betegvizsgálat lépéseit követve igyekezzünk minél pontosabban megmérni a beteg maghőmérsékletét, és azt követöen folyamatosan monitorozni is azt. A protokoll spontán légző beteg esetében, eszköz nélküli, vagy alapszintű légútbiztosító eszközök használata esetén a tympanicus hőmérők használatát, míg endotrachealis intubációt, vagy supraglottikus eszköz alkalmazását követően az oesophagiális maghőmérést részesíti előnyben. Az életjelek tekintetében a protokoll továbbra is azt javasolja, hogy annak ellenőrzése 
legfeljebb 1 percig tartson. Fontos hangsúlyozni, hogy hypothermiás beteg esetén a prehospitálisan megkezdett effektív melegítés, megfelelő betegellátás, gyors transzport, illetve a definitív ellátóhelyen történő aktív melegítés kulcsfontosságú a beteg életkilátásait tekintve.

\subsection{Megtartott eszméletü hypothermiás beteg prehospitális ellátása}

Ammenyiben azt tapasztaljuk, hogy a beteg maghőmérséklete $35^{\circ} \mathrm{C}$ alatt van, de kontaktusba vonható, úgy a részletes betegvizsgálatot követően döntsünk a következőkről: amennyiben a hypothermián kívül sérülései vannak a betegnek, úgy a legközelebbi kórházba javasolt a szállítás, ugyanakkor, ha kizárható bárminemű sérülés, kórok az alacsony maghőmérsékleten kívül, úgy mérlegelhetjük a beteg helyszínen hagyását. Elözetesen azonban ez esetben is szükséges a maghőmérséklet optimalizálásáról gondolkodni. A guideline szerint erre alkalmas lehet: meleg környezet és száraz, meleg öltözék biztosítása, édes meleg folyadék adása, aktív mozgatás kivitelezése.

\subsection{Eszméletlen, megtartott keringésü hypothermiás beteg prehospitális ellátása}

Amennyiben azt tapasztaljuk, hogy a hypotherm betegünk eszméletlen, úgy keresnünk kell a kardiális instabilitás jeleit. A protokoll szerint instabilitás jelként kell detektálni a 90 Hgmm alatti szisztolés vérnyomásértéket, továbbá bárminemű egyéb keringési instabilitásra utaló jelet. Az alacsony maghőmérséklet megítélésében a guideline különbséget tesz fiatal/egészséges és idős/mulimorbid egyének maghőmérséklete alapján a kardiális instabilitás tekintetében. Elmondható, hogy instabil jelként kell gondolni a $32^{\circ} \mathrm{C}$ alatti maghőmérsékletre idős/multimorbid egyének, és $30^{\circ} \mathrm{C}$ alatt fiatal /egészséges egyének esetén.

Abban az esetben a felsorolt kardiális instabilitás jelek közül nem tapasztalunk egyet sem, ugyanakkor eszméletlen a betegünk, úgy a következőket ajánlja a protokoll:

- A mentális státusznak megfelelő légútbiztosítás alkalmazása

- Immobilizálás, minimális mozgatása a betegnek kerülve a további hővesztést

- Az aktív külső melegítés megkezdése, kerülve az invazív melegítő módszereket.
Mivel a hypothermiás betegnél nem volt kardiális instabilitásra utaló jel, így a legközelebbi kórházba való szállítás szükséges.

Abban az esetben, ha a fentebb taglalt kardiális instabilitási jelek közül valamelyik tapasztalható a betegnél, úgy a protokoll Extracorporeal Life Support (ECLS) kivitelezésére alkalmas definitív ellátóhelyre javasolja szállítását, miközben - hasonlóan az instabilitás nélküli hypothermiá betegekhez - szükséges a prehospitális ellátás adekvát megkezdése és folytatása a speciális okok figyelembevételével.

\subsection{Megtartott keringés nélküli hypothermiás beteg prehospitális ellátása}

A $35^{\circ} \mathrm{C}$ alatti, spontán keringés nélküli beteg tekintetében a protokoll egyértelmüen meghatározza azokat a kritériumokat, amikor a prehospitális ellátó dönthet a CPR meg nem kezdése, vagy a megkezdett CPR felfüggesztése mellett. Ha nem biztonságos a helyszín, a biológiai halál biztos jelei, vagy az élettel összeegyezhetetlen okok azonosíthatóak, esetleg tudomására jut az ellátónak, hogy hivatalos okiratban nyilatkozott a beteg a CPR megkezdésének visszautasításáról (DNR), úgy megfontolható a fent említett döntés. Az ajánlás említi a lavina áldozatait, ami alapján a rossz a prognosztika miatt elhagyható a CPR megkezdése, ha a betemetődéstől eltelt idő legalább 60 perc, a légutakat hó fedi, illetve az iniciális ritmus asystolia volt.

Ugyanakkor, ha ezen tényezők nem állnak fenn, úgy a guideline alapján szükséges az újraélesztés azonnali megkezdése, és transzport közbeni folytatása mechanikus eszközzel. Abban az esetben, ha nem érhető el mechanikus mellkaskompressziós eszköz (pl: Lucas, AutoPulse), nehézkes a kimentés és/vagy a transzport, veszélyessé válik a helyszín, úgy az intermittáló, vagy késleltetett CPR alkalmazását javasolja a protokoll, melyet a 3. ábra szemléltet.

A guideline a CPR tekintetében kitér a sokkolandó ritmus észlelése esetén alkalmazandó defibrillációs technikákra, miszerint, ha a kamrafibrilláció (VF), vagy pulzus nélküli kamrai tachycardia (pnVT) a 3. sikeresen leadott sokkot követően is perzisztál, úgy szükséges annak szüneteltetése mindaddig, amíg a beteg maghőmérséklete eléri a $30^{\circ} \mathrm{C}$ feletti hőt. Gyógyszerelés 


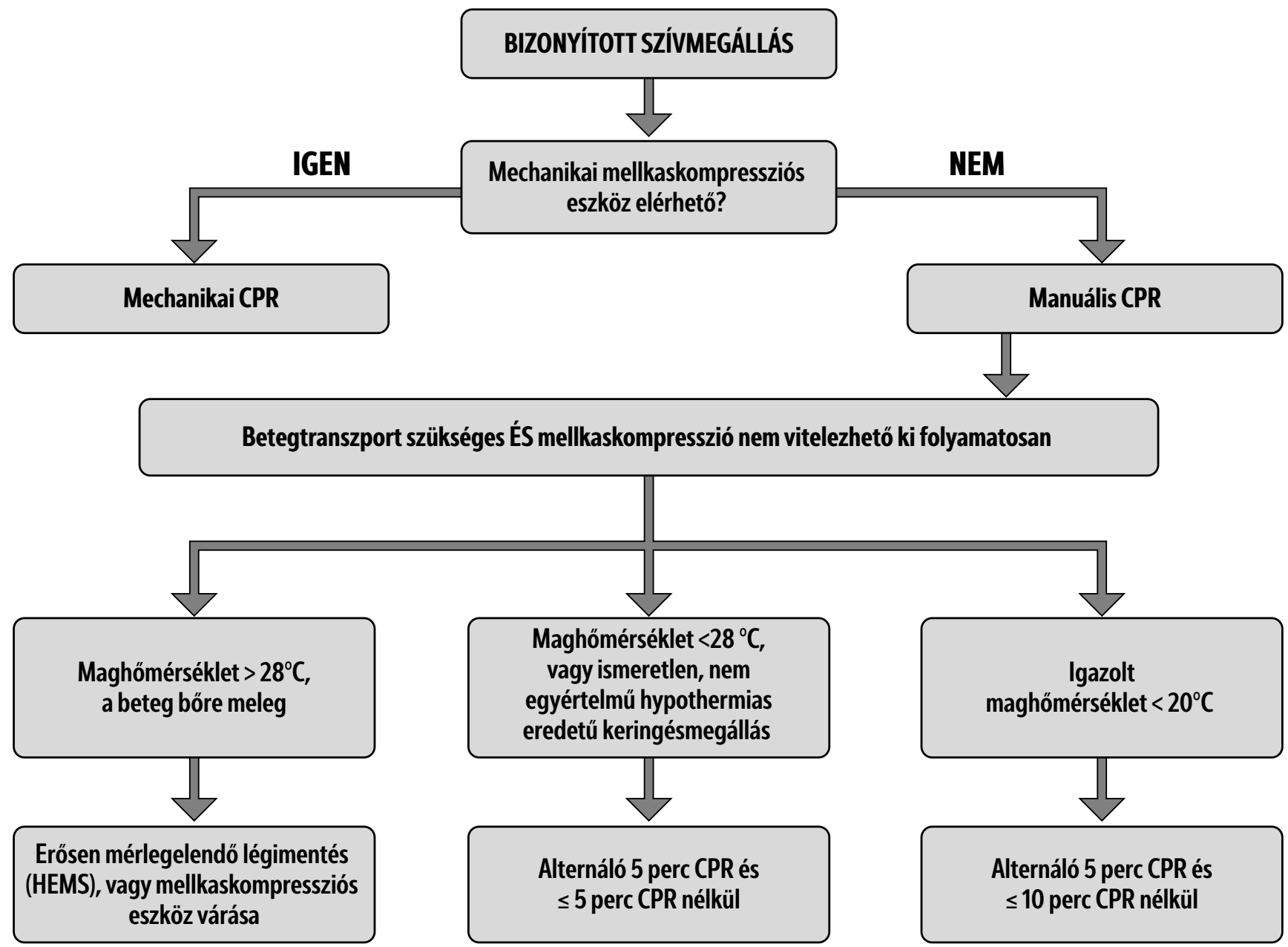

3. ábra: Intermittáló/késleltetett CPR alkalmazása(1)

tekintetében az ajánlás nem javasolja az adrenalin adását $30^{\circ} \mathrm{C}$ alatti maghőmérséklet esetén, és a 6-10 percenként javasolja adását $30^{\circ} \mathrm{C}$ felett.

A CPR kivitelezésé mellett szükséges az anamnesztikus adatok minél részletesebb gyüjtése és megismerése, hiszen a protokoll alapján meghatározott definitív ellátóhely ennek függvényében módosul. Abban az esetben, ha a kardiális arreszt állapot egyéb okból, lehülést megelőzően következett be, úgy az ajánlás alapján telefonos konzultáció mellett a legközelebbi ellátásra alkalmas kórházba javasolt a beteg szállítása. Ellenkező esetben speciális, ECLS-el rendelkező kórházba javasolt a szállítás folyamatos/intermittáló CPR mellett. A guideline alapján a megtartott keringésü, eszméletlen betegek esetén, amennyiben kardiális instabilitás fennáll és a prehospitális ellátó jelenlétében következik be az arreszt állapot, úgy hasonlóan ECLS-el rendelkező kórházba javasolt a beteg szállítása CPR mellett.

\subsection{Hypotermiás beteg intrahospitális} ellátása

Intrahospitálisan az ECLS megkezdése előtt javasolja a protokoll a rizikosratifikáció elvégzését a túlélés tekintetében. Ehhez a HOPE és ICE score használatát javasolja az ajánlás. Amennyiben a score rendszerek által meghatározott eredmények rossz prognosztikára utalnak, úgy megfontolható a CPR felfüggesztése. Abban az esetben, ha a HOPE, vagy ICE score alapján van esély a jó neurológiai kimenetelre, úgy megkezdhető a beteg visszamelegítése ECLS-el, ugyanakkor, ha ECLS nem érhető el 6 órán belül, akkor javasolt a CPR melletti non-ECLS melegítés $32{ }^{\circ} \mathrm{C}$ feletti maghőmérsékletre.

ROSC esetén, ha keringési instabilitás fennáll, fel kell készülni a sokszervi elégtelenség kezelésére, valamint az ECLS lélegeztetési támogatás szükségessége mellett a posztreszuszcitációs ellátásra. 
A Hypothermiás beteg ellátását összefoglaló folyamatot a 4. ábra mutatja be:

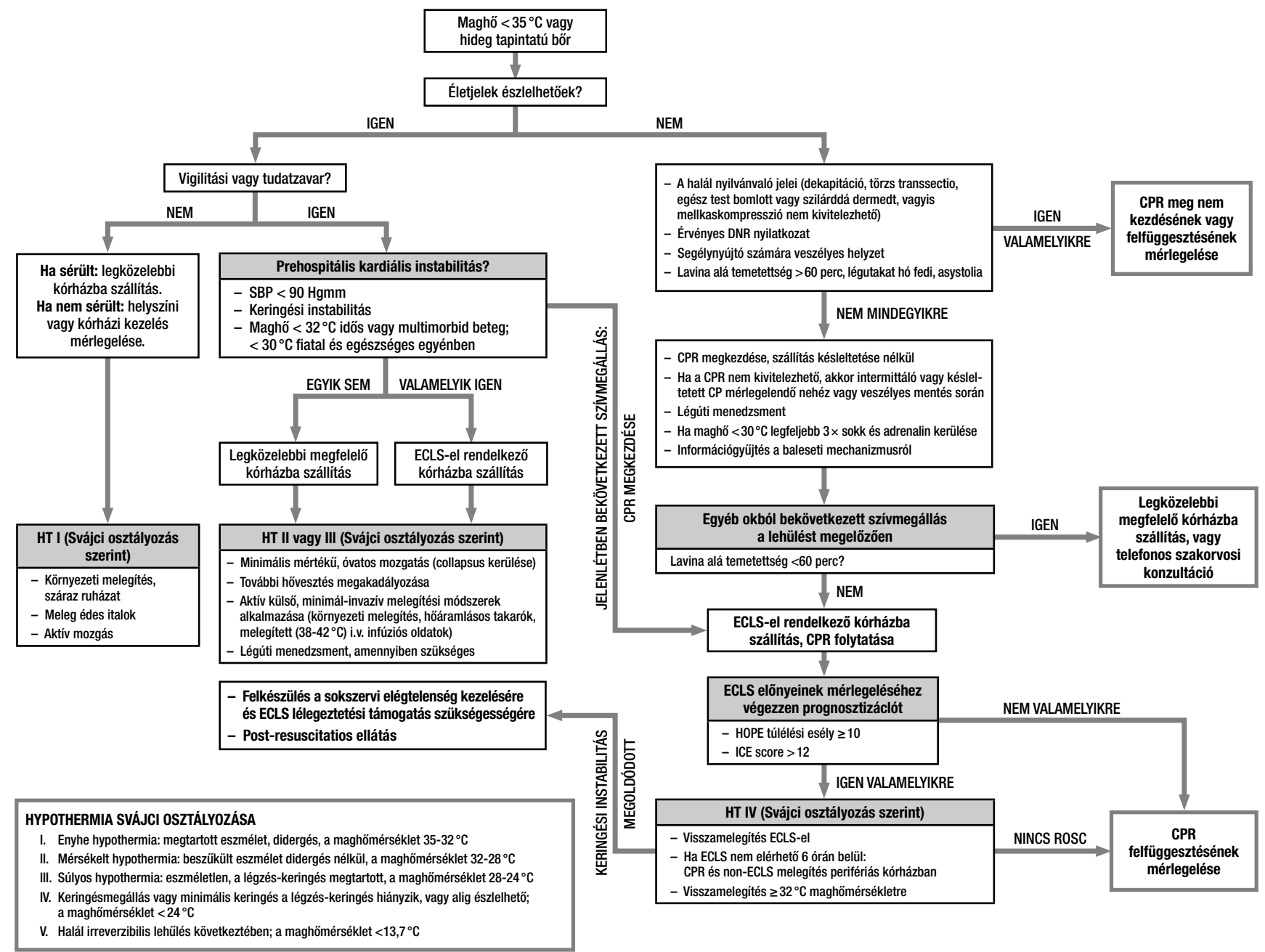

4. ábra: Hypothermias beteg ellátási algoritmusa (1)

\section{Hyperthermiás beteg ellátása}

Hyperthermiáról beszélünk, ha a test maghőmérséklete a normothermiának számító $36,5-37,5^{\circ} \mathrm{C}$ fölé emelkedik, aminek a hátterében a termoreguláció elégtelen működése áll. Az üvegházhatás fokozódása miatt napjainkban emelkedő tendenciát mutat azon betegek megjelenése, akik a környezeti hatások következtében kialakuló hyperthermia okozta egészségkárosodás miatt veszik igénybe az egészségügyi ellátórendszert. Az extrém időjárási viszonyok közül a hőhullámok okolhatók a legtöbb emberéletet követelő következetesen kialakuló hyperthermia miatt. (12) Európában 70000 ember hunyt el 2003-ban.(13) Legfőbb kockázatként az izzadás képességének hiánya jelölhető meg, ugyanakkor az időskor, és a különböző társbetegségek növelhetik a hyperthermia kialakulását. (14) A következőkben az ILCOR által elvégzett szisztematikus review alapján mutatjuk be a hyperthermiás betegek ellátására vonatkozó ERC protokollt. (15)

A guideline megfogalmazása alapján a hypothermiás beteg ellátásának kulcsa az idő, vagyis a minél korábbi hatékony hűtés megkezdését követően, késlekedés nélkül a megfelelő kórházba való szállítás. Három rövid utasítással aposztrofálható a protokoll alapján az eredményes ellátás:

- Azonnal, késlekedés nélkül megkezdett hütés

- Előszőr hűtés, majd a kórházba való szállítás megkezdése

- A gyors hütést folytatása $39^{\circ} \mathrm{C}$ alá, amíg a tünetek fennállnak 


\subsection{Megtartott keringésü hypothermiás felnőtt beteg ellátása}

Ha a beteg keringése megtartott és maghőmérséklete $\leq 40,5^{\circ} \mathrm{C}$, a protokoll a mentális státuszt megítélését várja el az ellátótól. Amennyiben nem tapasztalható zavartság vagy dezorientáció a betegnél, úgy a hatékony ellátás érdekében szükséges meghatározni a szérum nátrium szintet $(\mathrm{SeNa})$. Ha a $\mathrm{SeNa}$ nem alacsonyabb, mint $130 \mathrm{mEq} / \mathrm{l}$, úgy mérlegelni kell súlyos dehidráció egyidejü fennállását. Dehidráció hiányában keresni kell az egyéb kórokra jellemző tüneteket, panaszokat, és hiányukban fizikai aktivitás mellőzésének tanácsával otthonába bocsátható a beteg. Ellenkező esetben a tüneteknek megfelelő, protokoll által javasolt algoritmus követendő. Súlyos dehidráció fennállásakor orális (p.o.) rehidrációt javasol a guideline nátriumpótlással orientált beteg esetén, és intravénás (i.v.) fiziológiás sóoldat vagy Ringer-Laktát infúzió adását kóros mentális státusz esetén. Csökkent $\mathrm{SeNa}$ szint észlelésekor, orientált beteg esetében szintén p.o. nátrium pótlásást javasolt, azonban eszméletlen/ zavart betegnél 3\%-os sóoldat $(\mathrm{NaCl})$ bólusban való adását preferálja 10 perces időközönként intravénásan. Amennyiben szükséges, úgy a 3\%-os bólus $\mathrm{NaCl}$ maximum háromszor ismételhető, és megfontolandó a hiponatrémia protokoll alkalmazása.

Zavart tudatú beteg esetén, $40,5^{\circ} \mathrm{C}$ vagy azalatti maghőmérséklet esetén is a gyors hűtés megkezdését javasolja a protokoll, és folytatását mindaddig, míg a testhő $39^{\circ} \mathrm{C}$ alá nem csökken. A hútés alkalmazásával párhuzamosan meg kell határozni a beteg SeNa szintjét, és annak eredménye függvényében folytatni a betegellátást a fent leírtakhoz hasonlóan. Amennyiben elértük, hogy a beteg maghőmérséklete a hütés hatására $39^{\circ} \mathrm{C}$ alá csökken, további monitorizálás szükséges, legalább 15 percen keresztül. A monitorizálás során figyelni kell a rehidráció szükségességét és annak mértékét, a mentális státuszban történő változást, és el kell kerülni a hypothermia kialakulását $\left(<35^{\circ} \mathrm{C}\right)$.

A protokoll kitér rá, hogy amennyiben a beteg maghőmérséklete $\geq 40,5^{\circ} \mathrm{C}$, úgy azonnali gyors hütés javasolt hideg vízbe merítéssel. A hütésre legalkalmasabb „,recept”, ha egy fürdőkád félig, vagy háromnegyedig vízzel és jéggel kerül megtöltésre, aminek a hőfoka így 1-17 ${ }^{\circ} \mathrm{C}$ lesz. A hủtés szempontjából a cél ebben az esetben is a $39^{\circ} \mathrm{C}$ alatti testhőmérséklet elérése, figyelve

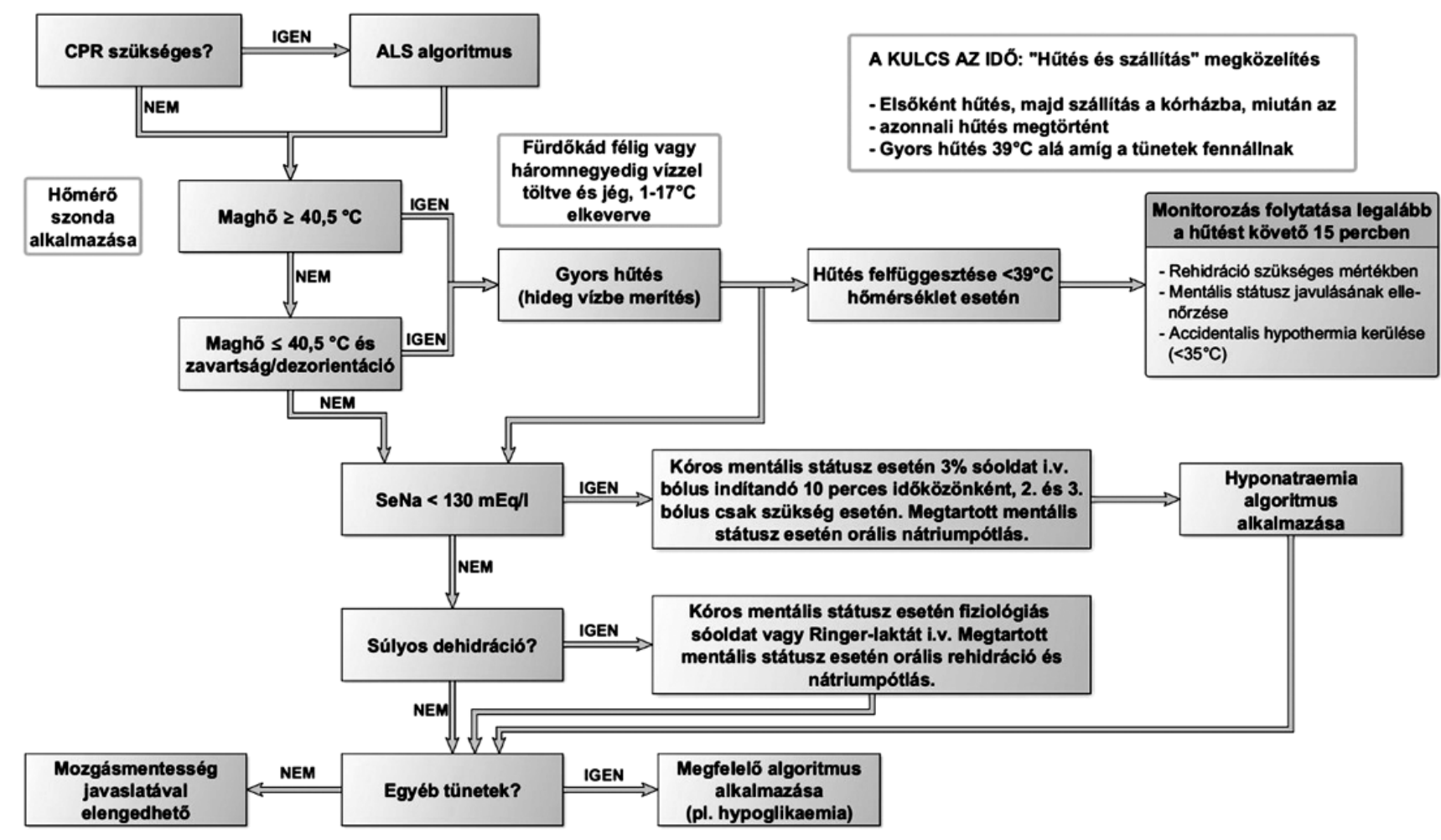

5. ábra: A hyperthermias beteg ellátási algoritmusa(1) 
a hypothermia elkerülésére. Ekkor is szükséges $\mathrm{SeNa}$ meghatározás, és amennyiben indikált, úgy i.v/i.o. gyógyszeres kezelés alkalmazása. A megfelelő maghőmérséklet elérését követően szükséges a beteg monitorozása legalább 15 percig, és figyelni a mentális állapotbeli változást, valamint a rehidráció szükségességét.

Abban az esetben, ha a betegnél nem tapasztalunk spontán keringést, úgy az univerzális ALS alkalmazását javasolja a protokoll.

A hyperthermiás beteg ellátására vonatkozó összefoglaló algoritmust a 5. ábra prezentálja:

\section{Szepszis}

A szepszis korai felismerésére is javasolt az ABCDE szemléletű betegvizsgálat. Ennek során az egyes vitális értékek elváltozásai, korábbi gyulladásos folyamatok beazonosítása segíthet a diagnózis felállításában. Az ajánlás a "Surviving Sepsis Campaign" -nel összhangban, 5 fó alappillérre hívja fel a figyelmet az első órák teendői között. A korai laktát szint meghatározása, hemokultúra mintavétel, széles spektrumú antibiotikum alkalmazása, $30 \mathrm{ml} / \mathrm{ttkg}$ bólusfolyadék mielőbbi beadása hypotenzív vagy $4 \mathrm{mmol} / \mathrm{L}$ laktátértékkel rendelkező beteg esetén, vasopresszorok alkalmazása folyadékra nem reagáló hypotenzív állapotokban, amennyiben az artériás középnyomás értéke nem éri el a 65 Hgmm-t. Keringésmegállás esetén kövessük a standard ALS algoritmust, újraélesztés közben adjunk $500 \mathrm{ml}$ bólusfolyadékot.

\section{Anaphylaxia}

Az anaphylaxia olyan súlyos, szisztémás allergiás reakciót okozó kórfolyamat, mely gyors, hatékony kezelés nélkül halált okozhat.(16) Globálisan szemlélve az anaphylaxia incidenciája növekszik, azonban a halálos kimenetelü esetek aránya stagnál, illetve csökken. A leggyakoribb anaphylaxiás reakciót kiváltó okok közt szerepel a rovarcsípés, étel-, és gyógyszerallergia.(17)

\subsection{Az anaphylaxia felismerése}

$\mathrm{Az}$ anaphyalxiás reakció esetén a következő tünetek megjelenésére kell figyelni, és felismerésére törekedni: az allergének hatására megduzzadhatnak az ajkak, a nyelv és az uvula is, aminek következtében stridoros légzési hang válhat hallhatóvá. Ezeken túl a beteg nehézlégzésről számolhat be, és akár szabad füllel hallható sípoló légzési hangot észlelhetünk.(18) A beteg bőre tekintetében generalizált csalánkiütés, kipirulás, viszketés, ami esetleg tapasztalható, ugyanakkor ezen elváltozások nem minden esetben vannak jelen, ahogyan a nyálkahártyaelváltozások sem. Súlyos anaphylaxia esetén rövid időn belül kialakuló hipotenzió és következményes szívmegállás is kialakulhat.(19) (20) A diagnózis felállításában segít a páciens kórtörténetében szereplö allergiás ágensek beazonosítása, ugyanakkor sokszor nem szerezhető ezirányú információ a betegtől. A protokoll megemlíti, hogy próbáljuk meg minél hamarabb eltávolítani az allergiát okozó triggert, ugyanakkor az ellátás megkezdését az nem késleltetheti.

\subsection{Az anaphylaxiás beteg ellátása}

A protokoll ajánlása szerint, miután ismertté vált, hogy súlyos anaphylaxiás reakcióval állunk szemben, kezdjük meg a beteg azonnali ABCDE betegvizsgálatát, a reakciót kiváltó trigger megszüntetésével párhuzamosan. Fontos, hogy az állapotrosszabbodás lassítása érdekében fektessük a beteget. Amint lehetséges adjunk a betegnek magas áramlású oxigént (94-98\%-os $\mathrm{SpO}_{2}$ elérése a cél), monitorozzuk fel, és biztosítsunk nagylumenű perifériás vénás utat. A gyógyszerelés tekintetében az anaphylaxiás sokk felismerését követöen azonnal adjunk a betegnek intramusculárisan (i.m.) 0,5 mg adrenalint $(0,5 \mathrm{ml}$ az $1 \mathrm{mg} / \mathrm{ml}$-es kiszerelésű Tonogen ampullából), és ismételjük annak adását abban az esetben, ha a beteg állapotában nem történik javulás az első adrenalin adását követő 5 percen belül. Intravénás adrenalin adása szoros monitorozás mellett, kizárólag megfelelő kompetenciaszint esetén mérlegelhető, melynek dózisa 20-50 $\mu \mathrm{g}$ titrálva. Ismételt adrenalin adás szükségessége esetén javasolt az infúziópumpa használata. Amint sikerült periférián nagylumenű vénát biztosítani, kezdjük meg krisztalloid oldat vagy $0,9 \%$-os $\mathrm{NaCl}$ oldat bólusban történő adását. A protokoll alapján a kezdeti folyadékbólus $500 \mathrm{ml}$ legyen, melyet lehetőleg 5-10 percen belül juttassunk a betegbe.

Alternatív keringéstámogatási lehetőségként javasolja a protokoll a vasopressin, noradrenalin, metaraminol, és a phenyleprine megfontolását refrakter anaphylaxiában, 
ugyanakkor javaslatként fogalmazza meg a guideline az 1-2 mg glucagon adását azon betegcsoportok körében, akik bétareceptor-blokkolót szednek.

A kutatások eredményeinek ismeretében a protokoll nem ajánlja a szteroidok és antihisztaminok rutinszerü alkalmazását anaphylaxiás sokk esetén, mivel elsődleges használatuk eredményességére nincsenek egyértelmü, bizonyítékokon alapuló evidenciák.

Arreszt állapot esetén szükséges az univerzális ALS azonnali megkezdése, és javasolt az ECLS vagy eCPR alkalmazásának megfontolása amennyiben elérhetők.

\section{$7 \mathrm{Az}$ asthma bronchiale és COPD beteg pre-arrest és arrest állapotainak ellátása}

A hörgi asztma (asthma bronchiale) és a krónikus légúti betegség (COPD) idült, időszakosan fellángoló kórfolyamata nagymértékben megviseli a legtöbb beteget, mely keringésmegállás esetén jelentős hátrányként jelenik meg az újraélesztés kimenetelét vizsgálva. A légzésmechanika és légzésszabályozás megváltozása, a beteg légzési izomzatának kimerülése, a szöveti oxigenizáltság bazálisan alacsonyabb szintje mindenképpen indokolja, hogy speciális körülményként kerüljön említésre az újraélesztési ajánlásokban.

\subsection{Pre-arrest ellátás}

Elsődleges célként a szívmegállás megelőzését, vagyis a pre-arrest időszak sikeres menedzselését említi az ajánlás (1). Ennek fóbb szempontjai, az ABCDE algoritmus szerint strukturálva a következők:

A- A beteg légútjának biztosítását és fenntartását követően az életet veszélyeztető hypoxia kezelésére nyílik lehetőség. Ez pulsoxymeter segítségével történő titrálással, nagy áramlási sebességű oxigénadással érhető el, melynek célértéke asthma bronchiale esetén $94-98 \%$, COPD betegek esetében pedig 88-92\% oxigénszaturációs érték.

B- Az ellátónak értékelni kell a beteg légzésszámát, segédizomhasználatát, beszédképességét (mely egész mondatok végigmondatásával vizsgálható), pulsoxymetrias leletét, fizikális vizsgálati eredményeit (auscultatio, percussio), illetve lehetőség szerint mellkas RTG vizsgálati leletét. A vizsgálatok alkalmával gondolni kell PTX (beleértve a feszülő forma) lehetőségére. Időben megkezdett lokális bronchodilátor kezelés (oxigénhajtású nebulizáció asthma bronchiale, kevert levegőporlasztással COPD esetén), szteroidkezelés (40-50 mg Prednisolon vagy $100 \mathrm{mg}$ Hydrocortison) segíthet az arrest elkerülésében, akárcsak i.v. Magnézium-szulfát adása asthma bronchiale betegnek. Aminophyllin és Salbutamol alkalmazása csak különösen indokolt esetben merül fel.

C- Szívfrekvencia és vérnyomás meghatározása segíti az ellátót az alkalmazott terápia mellékhatásainak felismerésében is. Készüljön a betegről 12 elvezetéses EKG. Intravénás út biztosítását követően i.v. folyadékbevitel is mérlegelendő.

\section{2 Újraélesztés specialitásai}

A kórfolyamat ismeretében nem meglepő, hogy döntően a lélegeztetés szempontjából fogalmaz meg speciális szempontokat az ajánlás. Ezen belül magas áramlással, nagy koncentrációban javasolja az oxigénadást, a lélegeztetés mindenképpen a mellkas emelkedéséhez szükséges töltőtérfogattal történjen, 8-10/perc frekvenciával. Amennyiben az ellátó kellő gyakorlattal rendelkezik, endotrachealis intubatio javasolt. A tensios PTX jeleit keressük (folyamatosan, még ha korábban meg is történt), fennállása esetén kezeljük. A tüdőparenchymat károsító hyperinflatio elkerülése érdekében az IPPV-ről történő lecsatlakoztatás, majd a térfogat mellkasra gyakorolt nyomással történő csökkentése válhat indokolttá. Intravénás infúziós kezelés mérlegelése szükséges. Amennyiben az első újraélesztési kísérletek sikertelenek, a helyi protokolloknak és adottságoknak megfelelően eCPR mérlegelendő.

\section{Ionháztartás zavarai}

A fiziológiai folyamatokáltal szabályozott homeosztázis fontos tényezője az ion- és töltéseloszlás állandósságának biztosítása. Az elektrofiziológiai folyamatok, így az nyugalmi membránpotenciál, akciós potenciál, idegrendszeri jelátvitel, izomműködés és a transzportfolyamatok is igénylik ennek állandósságát. Éppen emiatt is indokolt, hogy a 2021-es újraélesztési ajánlás(1), a speciális újraélesztési körülmények között, külön is 
foglalkozik a fontosabb, ionzavarok következtében kialakuló pre-arreszt és arreszt állapotokkal.

Minden esetben gondolni kell ionzavarra, amikor szívritmuszavart észlel a sürgősségi ellátó. Ilyenkor point of care testing (POCT) alkalmazásával javasolt a káliumszint meghatározása, azonban nyugodtan támaszkodhatunk a leginkább elérhető EKG diagnosztikára a gyanú megfogalmazásakor. Az életet veszélyeztető szívritmuszavarok kialakulásának legjelentősebb, ionháztartási zavaron alapuló okai a kálium zavarok, a hyperkalaemia és a hypokalaemia. Ritkábban kalcium vagy magnéziumzavar (is) azonosítható ennek okaként. Nem meglepő tehát, hogy az ajánlás legrészletesebben a hyperkalaemia kezelésével foglalkozik.

\subsection{Hyperkalaemia}

A hyperkalaemia a kórházi betegek 1-10\%-ában azonosítható, a kórházon belüli szívmegállások (in hospital cardiad arrest - IHCA) 1-13\%-áért tehető felelőssé. (21) Kiemelten érinti a művesekezelt betegeket, hiszen alapbetegségük hajlamosító tényezőként szerepel a hyperkalaemia esetében, ugyanakkor a szívbetegségekre való hajlamukkal együttesen jelentkező ionzavar nagyban megnöveli a hirtelen szívhalál kockázatát.

5,5 mmol/1 plazmakoncentráció felett mért káliumszint esetén már hyperkalaemiaról beszélünk, azonban a káliumszint emelkedésével párhuzamosan szélesülő tünettan az ionzavar súlyosság szerinti csoportosítását igényli. Eszerint megkülönböztethetünk enyhe (5,5-5,9 mmol/l közötti káliumszint), közepesen súlyos (6,0$6,4 \mathrm{mmol} / \mathrm{l})$ és súlyos ( $\geq 6,5 \mathrm{mmol} / \mathrm{l})$ hyperkalaemia. A szérumszint mellet azonban fontos az EKG eltérések szerinti csoportosítás is, mely alapján elkülöníthetünk EKG eltéréssel (I. fokú AV-blokk, ellapult vagy hiányzó p hullámok, magas-csúcsos T hullámok, ST szakasz depresszió, kiszélesedett kamrai komplexumok, kamrai tachycardia, bradycardia, szívmegállás: PEA, $\mathrm{VF} / \mathrm{pVT}$, asystolia) járó klinikai formát (jellemzően a közepesen súlyos és súlyos csoportokon belül), valamint EKG eltéréseket nem okozó eseteket.
A hyperkalaemia okait foglalja össze az 1. Táblázat.

\begin{tabular}{|l|}
\hline Gyógyszerek \\
\hline Angiotenzisn konvertáló enzim (ACE) inhibitorok \\
\hline Angiotenzin-II receptor blokkolók (ARB) \\
\hline Mineralokortikoid receptor antagonisták (MRA) \\
\hline Nem-szteroid gyulladáscsökkentó szerek (NSAID) \\
\hline Nem szelektív béta receptor blokkolók \\
\hline Trimethoprim \\
\hline Suxametonium-klorid \\
\hline Veseelégtelenség \\
\hline Akut vesesérülés (AKI) \\
\hline Krónikus vesebetegség (CKD) \\
\hline Végstádiumú vesebetegség (ESRD) \\
\hline Endokrin betegségek \\
\hline Diabeteszes ketoacidózis \\
\hline Addison kór/szindróma \\
\hline Szövetpusztulás \\
\hline Rhabdomyolysis \\
\hline Tumor lízis szindróma \\
\hline Hemolízis \\
\hline
\end{tabular}

1. Táblázat: A hyperkalaemia okai

A fenti potenciális kórokok mellett mindenképpen hyperkalaemiára kell gondolni, amennyiben szívritmuszavart vagy szívmegállást észlel az ellátó, különösen a veszélyeztetett rizikócsoportba tartozó betegek esetén. Ettől függetlenük a hyperkalaemia szívritmuszavar nélkül is jelentkezett, noha ekkor általában nem jelent közvetlen pre-arreszt állapotot. Habár hyperkalaemia esetén is az EKG a legelérhetőbb és legkézenfekvőbb diagnosztikus eszköz, ez leginkább a cardiotoxicitás azonosításában játszik kulcsfontosságú szerepet, meghatározva ezzel a kardioprotektiv terápia szükségességét.

A helyzetet tovább nehezíti, hogy gyakran tünetmentesen jelentkezik az ioneltérés, vagy a kóroki tünettan elfedi ezeket. Gyakori jel mindemellett a paraesthesia, végtaggyengeség vagy petyhüdt (flaccid) bénulás. 
Fentiek okán, amennyiben a klinikai gyanú felmerül, elérhetősége esetén mindenképp javasolt POCT keretében (például ASTRUP készülék segítségével) a szérum káliumszint meghatározása! Mindezzel együtt, a súlyos kardiotoxikus állapotra utaló jelként észlelt EKG eltérések esetén az oki terápiát a laboratóriumi eredmény rendelkezésre állásáig is meg lehet, illetve meg kell kezdeni!

Akkor jár el helyesen az ellátó, amennyiben az ABCDE algoritmust követve vizsgálja a beteget, kiegészítve sürgősségi laboratóriumi vizsgálattal (különösen POCT kálium meghatározással), valamint értékeli az EKG eltéréseket (mely mindenképpen indokolja annak monitorozását). A terápiát ugyanis a szérum káliumkoncentráción alapuló súlyosság és a keringést veszélyeztető EKG eltérések megléte alapján jelöli ki a referált ajánlás, mely a hyperkalaemia enyhe eseteinek kezelésével nem foglalkozik.

A terápiás stratégia 5 pilléren nyugszik(22):

1. Myocardium-protekció

2. Intracelluláris kálium shift

3. Kálium eltávolítását célzó terápia

4. Szérum kálium- és glükóz-szint monitorozása

5. A hyperkalaemia eredményes kezelést követő visszatérésének megelőzése

Ad 1: EKG eltérések megléte esetén mindenképp indokolt a membránstabilizáló terápia, mely a keringésmegállást potenciálisan eredményező ritmuszavarok megelözését szolgálja, habár erre vonatkozóan továbbra sem áll rendelkezésre megalapozott bizonyíték. Kalcium-sók (így kalcium-klorid vagy kalcium-glukonát) alkalmazása indokolt súlyos, EKG eltérésekkel kísért esetekben. Kockázatként az extravasatio következtében fellépő szöveti nekrózis emelendő ki, mely rávilágít arra, hogy alkalmazását megelőzően stabil vénás bejuttatási útról gondoskodni szükséges.

Ad 2: A szérum ionizált káliumkoncentráció csökkentésének egyik hatékony módszere a kálium intracelluláris térbe mozgattatása, mely céljából elsőként választandó módszerként az ajánlás az inzulin-glükóz terápiát javasolja. Ennek legsúlyosabb kockázata a hypoglikaemia (különösen a terápia előtt már alacsony vércukorszinttel rendelkező betegek esetében), mely csökkenthető további vagy folyamatos intravénás glükóz bejuttatással. Habár alacsonyabb shift-dózissal (5 NE inzulin) is zajlanak klinikai vizsgálatok, a sztenderd dózis (10 NE inzulin és 25 g glükóz) hatásosabbnak tűnik, így ennek alkalmazását javasolja az ajánlás. $7 \mathrm{mmol} / \mathrm{l}$ bazális vércukorszint alatt ennek 25 gramm ( 5 óra alatt, 10\%-os glükóz oldattal) intravénás cukorinfúzióval történő kiegészítése javasolt. Ugyancsak az intracelluláris kálium shift-et célozza a beta-1 adrenoceptor izgatása, mely céljából Salbutamol nebulizálandó a betegnek, azonban monoterápiaként nem, mindössze az inzulin-glükóz terápia kiegészítéseként alkalmazandó.

Ad 3: A káliumkötésre használt Resonium mellett újabb típusú szerek alkalmazása is bekerült a protokollba. A nátrium-cirkónium-cikloszilikát (SZC) 1 órás hatáskezdet mellett körülbelül $1,1 \mathrm{mmol} / 1$ káliumszintcsökkentést képes elérni 48 órán belül, mely a szérum káliumszint koncentrációval összefügg, így magasabb szérum káliumszint növeli a kötőképességet. Ugyancsak feltünik az ajánlásban a Patiromer, mely lassabban fejti ki, kevésbé intenzív káliumkötő hatását. Mindkét gyógyszer alkalmazhatóvá vált a hyperkalaemia enyhébb eseteiben, azonban nem a dializált krónikus vesebetegek és aluldozírozott ACEinhibitor vagy $\mathrm{ARB}$ terápiában részesülő szívelégtelen betegek esetében. Ezekben az esetekben a hagyományos káliumkötő gyanták (például Resonium) alkalmazása javasolt.

A kálium eltávolítása sürgősségi dialíziskezeléssel a következő esetekben indokolt:

- Súlyos, életet veszélyeztető hyperkalaemia, akár EKG eltérések nélkül is

- Végstádiumú veseelégtelen betegek esetében

- Oliguriával (<400 ml/nap) járó akut vesebetegség

- Jelentős szövetpusztulás (például rhabdomyolysis)

Ad 4: Tekintettel arra, hogy a fenti terápiák hatástartama rövid (inzulin-glükóz és Salbutamol esetében 4-6 órás hatástartammal számolhatunk), a hyperkalaemia visszatérésének, illetve a hypoglikaemia elkerülése érdekében a szérum káliumkoncentráció és vércukorszint többszöri kontrollálása megkerülhetetlen.

Ad 5: A folyamatos monitorozás mellett a hyperkalaemia okainak (1. Táblázat) feltárása is hozzájárul viszszatérésének elkerüléséhez. 


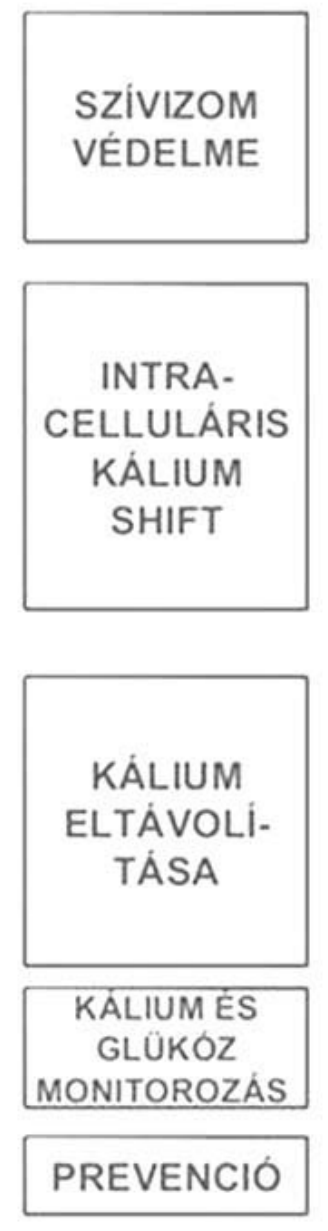

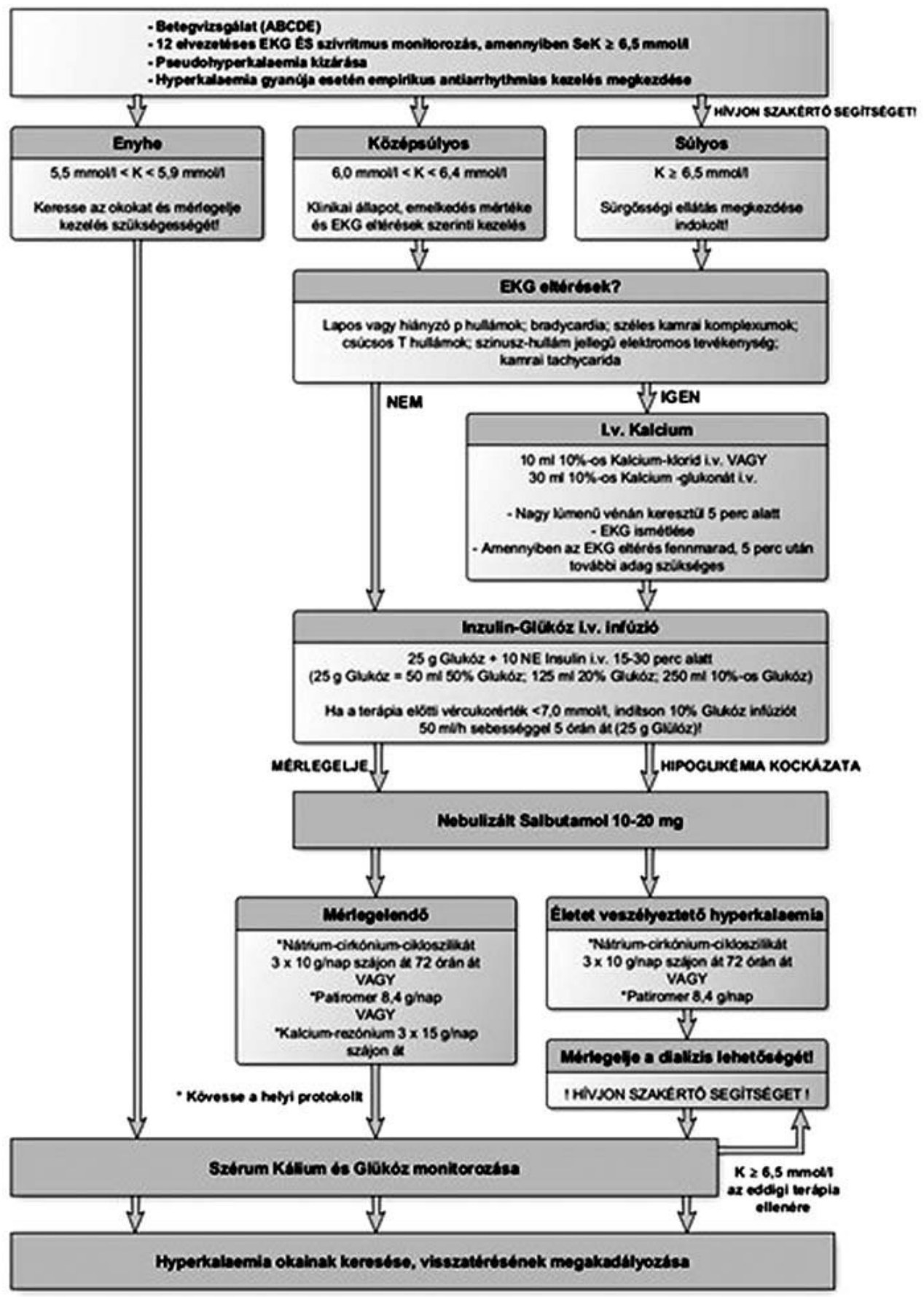

6. ábra: A hyperkalaemia ellátási algoritmusa(1)

\subsection{Hypokalaemia}

A 3,5 mmol/ koncentráció alatti kálium plazmaszint, azaz a hypokalaemia gyakori elektrolitzavar, különösen a szívbetegek és a digitáliszt szedők körében. Magas kórházi halálozással jár, mely összefügg a kamrai ritmuszavart eredményező természetével. Hasonlóan a hyperkalaemiához, a hypokalaemia esetén is megkülönböztethetünk enyhe (3,1-3,4 mmol/l plazma káliumszint), középsúlyos (2,5-2,9 $\mathrm{mmol} / \mathrm{l})$ és súlyos $(<2,5 \mathrm{mmol} / \mathrm{l})$ eseteket. Gyakran tapasztalható hypomagnesaemiával együttes előfordulása, a magnézium ugyanis fontos szerepet tölt be az intracelluláris káliumkoncentráció fenntartásában, egyik fontos tényezője a káliumfelvételnek, különösen a myocytákban. A magnézium korrekciója így hozzájárul a káliumszint gyorsabb emeléséhez.(23) 
Hasonlóan a hyperkalaemiához, minden arrhythmia vagy szívmegállás esetén gondolni kell hypokalaemia lehetőségére. A káliumszint csökkenésével az akciós potenciál folyamata különösen érintett, így gyengeséget, fáradtságot, székrekedést és lábikragörcsöt is okoz a betegnek. Habár az enyhe hypokalaemia gyakran tünetmentes, súlyosabb esetekben fokozódó paresis, rhabdomyolysis, nehézlégzés és szívritmuszavar is kialakulhat. Az EKG az ellátó segítségére lehet a differenciáldiagnosztikában, amennyiben megjelennek u hullámok, ellapulnak a T hullámok, megnyúlik a PQ/ PR időtartam, ST szakasz depresszió fejlődik ki, akár T inverzióval, emellett, ahogy korábban már említettük ritmuszavar jelenik meg (különösen digitalizált betegek esetében) vagy szívmegállás (VF/pVT, PEA, asystolia) észlelhető.

Hypokalaemiát eredményező kórokokat foglalja össze a 2. Táblázat.

\begin{tabular}{|l|}
\hline Gasztrointesztinális vesztés \\
\hline Hasmenés \\
\hline Hashajtó abúzus \\
\hline Vastagbél adenoma \\
\hline Renalis vesztés \\
\hline Renális tubuláris betegségek \\
\hline Diabetes insipidus \\
\hline Dialízis kezeléshez kapcsolódó vesztés \\
\hline Gyógyszerek \\
\hline Diuretikumok \\
\hline Laxatívumok \\
\hline Hyperkalaemia intracellularis shift kezelése (inzulin-glükóz \\
vagy salbutamol) \\
\hline Endokrin betegségek \\
\hline Cushing szindróma \\
\hline Primer hipoaldoszteronizmus \\
\hline Egyéb \\
\hline Magnéziumvesztés \\
\hline Metabolikus alkalózis \\
\hline Csökkent bevitel (étrendi hiba) \\
\hline
\end{tabular}

2. Táblázat: A hypokalaemia fóbb kórokai
A terápia kulcspontjai(23):

1. Káliumkoncentráció korrekciója

2. Kiváltó, illetve súlyosbító tényezők azonosítása (különösen a hypomagnesaemia, digitálisz hatás)

3. Szérum káliumszint monitorozása, a terápia ütemének és időtartamának ennek megfelelő felülvizsgálata

4. Eredményes kezelést követő visszatérésének megelőzése (kiváltó okok felismerése és kezelése)

Ad 1: A káliumpótlás sztenderd üteme $10 \mathrm{mmol} / \mathrm{h}$. A káliumbevitel sebességét azonban a kiindulási koncentráció, vagyis a súlyosság mértéke, továbbá a klinikai kép határozza meg, azonban maximális mértéke $20 \mathrm{mmol} / \mathrm{h}$. Fenyegető szívmegállás (instabil ritmuszavarok) esetén javasolt gyorsabb pótlási sebesség is (például $2 \mathrm{mmol} / \mathrm{min} 10$ percen át, majd $10 \mathrm{mmol}$ 5-10 percenként).

Ad 2: Ahogy láttuk a magnéziumpótlás elősegíti a káliumpótlás folyamatát, a hypomagnesaemia nem egyszer oka is a szérum káliumkoncentráció csökkenésének, így amennyiben a hypokalaemiával együttesen fennáll $8 \mathrm{mmol}$ (4ml 50\%-os) Magnézium- szulfát adása indokolt 20 perc alatt, $10 \mathrm{ml}$ fiziológiás $(0,9 \%)$ sóoldatban hígítva, melyet káliumpótlás $(40 \mathrm{mmol}$

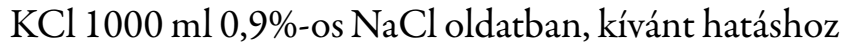
szükséges sebességgel) kell kísérjen. Szükség esetén a magnéziumpótlás folytatható.

A terápia során elengedhetetlen a folyamatos EKG, és szérum káliumszint monitorozása.

\subsection{Hypercalcaemia}

Hypercalcaemia $(\mathrm{SeCa}++>2,6 \mathrm{mmol} / \mathrm{l})$ primer vagy tercier hyperparathyreosysban, paraneopláziaként (rosszindulatú tumoros betegség kísérőállapotaként), sarcoisdosisban és gyógyszerhatás (például D-vitamin túladagolás, thiazid típusú diuretikum hatás) következtében alakul ki.

Főbb, felismerést segítő tünetei: zavartság, gyengeség, hasi fájdalom, hypotensio, szívritmuszavarok, akár szívmegállás. Jellemző EKG eltérések: megrövidült QT idő, kiszélesedett kamrai komplexumok, lapos T hullámok, AV-blokk megjelenése. 
A terápia föbb lépései: intravénás folyadékbevitel, Furosemid ( $1 \mathrm{mg} / \mathrm{ttkg}$ i.v.), Hidrokortizon (200-300 mg i.v.), bisphosphonat (Pamidronat 30-90 mg i.v.), továbbá a kiváltó ok(ok) kezelése.

\subsection{Hypocalcaemia}

Hipokalcémia (SeCa $++<2,1 \mathrm{mmol} / \mathrm{l})$ leggyakrabban krónikus veseelégtelenség, akut pancreatitis, kalciumcsatorna blokkoló túladagolás, toxikus sokk szindróma, rhabdomyolysis és tumor-lízis szindróma következtében alakulhat ki.

Főbb tünetei: paraesthesia, tetánia, harántcsíkolt izomgörcs rohamok, AV-blokk és szívmegállás. Detektálható EKG eltérések: megnyúlt QT idő, T hullám inverzió, $\mathrm{AV}$-blokk.

Terápiás lehetőségek: 10\%-os Kalcium-klorid 10-40 ml i.v., 50\%-os Magnézium-szulfát 4-8 mmol i.v. (amenynyiben szükséges).

\subsection{Hypomagnesaemia}

A hypokalaemiával gyakran együtt jelentkező hypomagnesaemia (SeMg+ $+<0,6 \mathrm{mmol} / \mathrm{l})$ leggyakoribb okai az alkoholizmus, gastrointestinalis vesztés, éhezés, malabsorptio, poliuria.

Főbb tünetei: tremor, ataxia, nystagmus, harántcsíkolt izomgörcs rohamok, szívritmuszavarok, különösen Torsade de Pointes (TdP) kamrai tachycardia, akár következményes szívmegállás. Kisérő EKG eltérések: PR és QT idők megnyúlása, ST szakasz depresszió, T hullám inverzió, lapos p hullámok, kiszélesedett kamrai komplexumok, TdP VT.

Terápiája: súlyos, tünetekkel kísért esetben 2 g 50\%-os Magnézium-szulfát $(4 \mathrm{ml}, 8 \mathrm{mmol})$ i.v. 15 perc alatt, TdP kamrai tachicardia esetén: 2 g 50\%-os Magnézium-szulfát $(4 \mathrm{ml}, 8 \mathrm{mmol})$ i.v. 1-2 perc alatt, harántcsíkolt izomgörcs esetén ugyanezen dózis 10 perc alatt történő intravénás beadással.

\subsection{Hypermagnesaemia}

Hypermagnesaemia $(\mathrm{SeMg}++>1,1 \mathrm{mmol} / \mathrm{l})$ szinte kizárólag szívelégtelenség vagy iatrogén ártalom következtében alakul ki.
Főbb tünetei: zavartság, gyengeség, légzésdepresszió, AV-blokk, akár következményes szívmegállás.

Terápiás lehetőségek: $1,75 \mathrm{mmol} / 1$ szérum-koncentráció felett merül fel, ekkor 10\% Kalcium-klorid 5-10 ml i.v., szükség szerint ismételve, só-diuresis: Furosemid (1 $\mathrm{mg} / \mathrm{ttkg}$ i.v.) 0,9\%-os sóoldattal együttesen alkalmazva, haemodialysis, szükség esetén mesterséges lélegeztetés.

\section{Mérgezett beteg}

Habár toxikológiai kórok viszonylag ritkán okoz keringésmegállást (24), az ajánlás külön alfejezetben foglalkozik a mérgezett betegek ellátási specialitásaival ( 7 . ábra).

A keringésmegállás megelőzésének sarkalatos lépései a vérnyomáscsökkentés (melyre benzodiazepin, vazodilatátor és tiszta alfa-receptor antagonista kezelést javasol a protokoll), az intravénás folyadékadásra általában jól reagáló hypotensio kezelése, a szívritmuszavarok toxikológiai kórókra specifikus kezelése, a korai légútmenedzsment és a rendelkezésre álló antidótum lehető legkorábbi alkalmazása.

Keringésmegállás esetén elsődleges szempont az személyes védelme, melynek alacsony küszöbünek kell lennie. A specifikus terápiás lépések tervezése érdekében mérlegelni szükséges a lehetséges antidótumokat, dekontaminációs és eliminációs lehetőségeket. Kénhidrogén, cianid, marószer és organofoszfát mérgezés esetén befúvásos lélegeztetés alkalmazása kerülendő. Mindenképpen szükséges a keringésmegállás indirekt okát is jelenteni képes reverzibilis okok mindegyikének kizárása. Gyógyszermérgezés esetén gyakori a hypo- és hyperthermia, így megkerülhetetlen a testhő mérése. Hatásos újraélesztéssel fenntartott keringés és metabolizmus hatására a toxin koncentrációja csökkenhet, így fel kell készülni a hosszabb ideig elnyúló újraélesztésre. A ritka és speciális ellátási igénnyel bíró mérgezések ellátását megkönnyíti a regionális vagy országos toxikológiai központokkal történő, akár telefonos konzultáció. Amennyiben elérhető, az eCPR lehetősége mérlegelendő bizonyos esetekben, amennyiben a konvencionális újraélesztés nem vezet sikerre. 


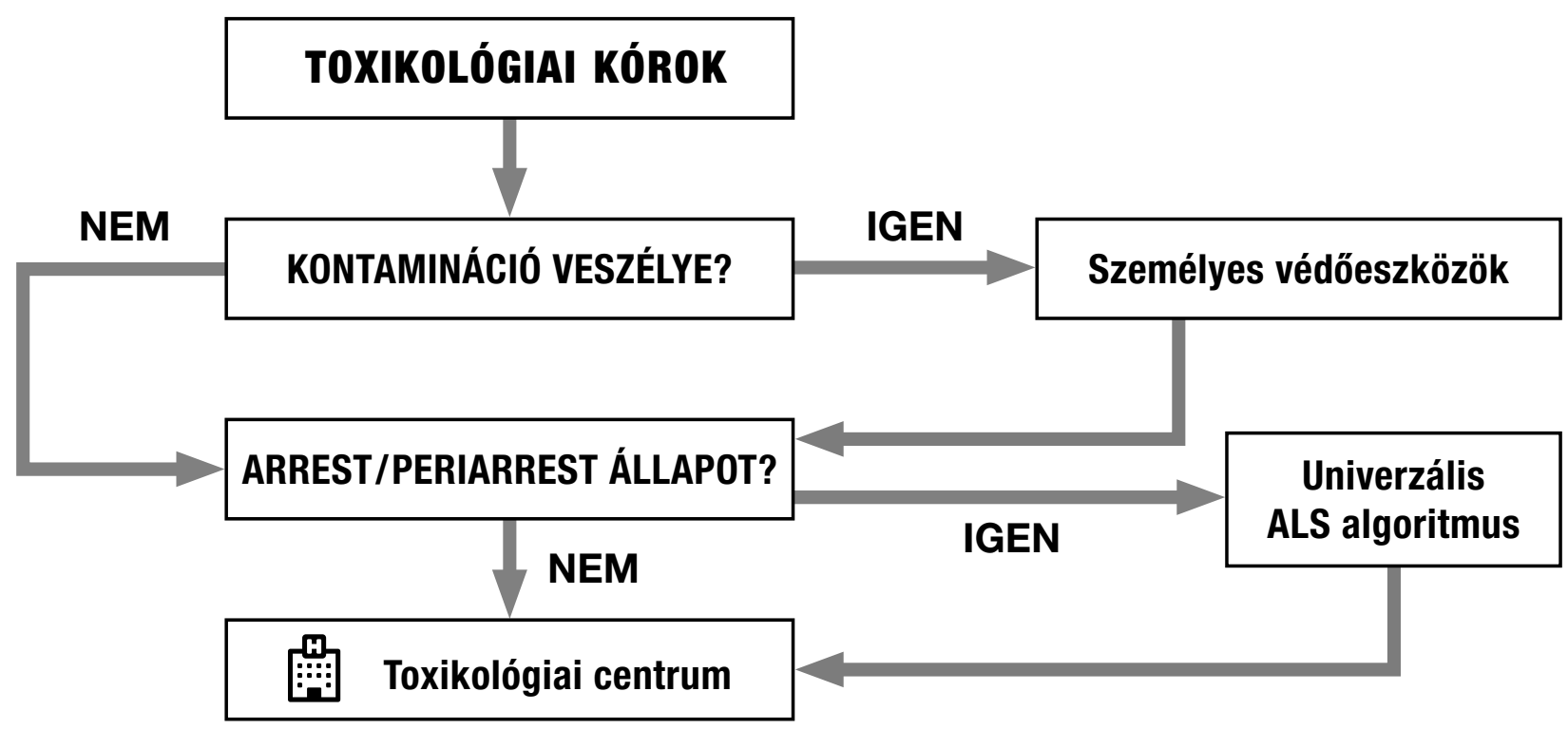

\begin{tabular}{|l|}
\hline \multicolumn{1}{|c|}{ AMENNYIBEN INDOKOLT } \\
\hline - Dekontamináció \\
- Fokozott elimináció \\
- Antidotum \\
\hline
\end{tabular}

- Befúvásos lélégeztetés kerülése

- Folyamatos újraélesztés

- Magasabb dózisú gyógyszerelés

- Törekedjen azonosítani a toxikus okot

- Mérlegelje a hypo- és hyperthermia lehetőségét

- Zárja ki valamennyi reverzibilis okot

7. ábra: A toxikológiai beteg ellátási algoritmusa

A specifikus terápia főbb lépéseit foglalja össze a követ-

kező, 3. táblázat.

Mérgezö ágens

Első vonalbeli szer

Mérlegelendő

Kerülendő

Kardiovaszkuláris és neurológiai gyógyszerek

\begin{tabular}{|l|l|l|l|}
\hline Digoxin & Kamrai ritmuszavar esetén Lidokain & Digoxin Fab $80 \mathrm{mg}$, sz.e. ismételve & $\begin{array}{l}\text { Kalcium-csatorna blok- } \\
\text { kolók, la szerek }\end{array}$ \\
\hline Kalcium-csatorna blokkolók & $\begin{array}{l}10-20 \text { percenként 1-2 } \mathrm{g} \text { Calcium i.v. } \\
\text { Nagy dózisú Insulin(25),(26) } \\
\text { Katekolamin } \\
\text { Atropin }\end{array}$ & PM terápia, VA-ECM0, i.v. lipid emulsio & \\
\hline Triciklikus antidepresszánsok & $\begin{array}{l}\text { Széles kamrai komplexumú kamrai ritmuszavar } \\
\text { esetén bikarbonát (1-2 mmol/ttkg), cél pH 7,45-7,55 }\end{array}$ & I.v. lipid emulsio & \\
\hline
\end{tabular}




\begin{tabular}{|c|c|c|c|}
\hline Mérgezó ágens & Első vonalbeli szer & Mérlegelendö & Kerülendö \\
\hline Neuroleptikumok & $\begin{array}{l}\text { Széles kamrai komplexumú kamrai ritmuszavar } \\
\text { esetén bikarbonát (1-2 mmo//ttkg) } \\
\text { Dantrolene } \\
\text { Bromocriptine }\end{array}$ & & $\begin{array}{l}\text { Dopamin } \\
\text { Adrenalin } \\
\text { Dobutamin }\end{array}$ \\
\hline Antiepileptikumok & $\begin{array}{l}\text { Széles kamrai komplexumú kamrai ritmuszavar } \\
\text { esetén bikarbonát (1-2 mmol/ttkg) } \\
\text { Dantrolene } \\
\text { Carnitine, Naloxon - (valproát-mérgezés esetén) }\end{array}$ & $\begin{array}{l}\text { Haemodialysis } \\
\text { ECLS Carbamazepine }\end{array}$ & \\
\hline Benzodiazepinek & & Flumazenil & \\
\hline Helyi érzéstelenítők & $\begin{array}{l}\text { I.v. lipid emulsio: } 20 \% 1,5 \mathrm{ml} / \mathrm{ttkg} 1 \text { perc alatt, majd } \\
0,25 \mathrm{ml} / \mathrm{ttkg} / \mathrm{min} \text { infúzió } 60 \text { percen át. } 2 \text { bólus } \\
\text { ismétlés, maximális összdózis } 12 \mathrm{ml} / \mathrm{ttkg}\end{array}$ & & \\
\hline \multicolumn{4}{|l|}{ Kábítószer abúzus szerei } \\
\hline Opioidok & Naloxone 0,4-2 mg, 2-3 percenként ismételhető & & \\
\hline Kokain & Benzodiazepinek & $\begin{array}{l}\text { Alfa-receptor blokkolók, kalcium-csatorna } \\
\text { blokkolók, nitroglicerin (hypertensio esetén) }\end{array}$ & $\begin{array}{l}\text { Béta-receptor blokkoló } \\
\text { a terápia kezdetén }\end{array}$ \\
\hline Amphetamin & Benzodiazepinek (görcsgátlás) & $\begin{array}{l}\text { Cyproheptadine, Chlorpromazine, } \\
\text { Ziprasidone (szerotoninerg szindróma } \\
\text { esetén) }\end{array}$ & \\
\hline \multicolumn{4}{|l|}{ Asphyxiat okozó szerek } \\
\hline Cianidok & Hydroxycobalamine $70 \mathrm{mg} / \mathrm{ttkg} 1-3$ perc alatt & Natrium-thiosulfate & $\begin{array}{l}\text { Amyl-nitrit, Natrium-nitrit } \\
\text { (füstbelégzés esetén) }\end{array}$ \\
\hline Szén-monoxid & Oxigén & Hyperbaricus oxygenterapia & \\
\hline Kén-hidrogén & $\begin{array}{l}\text { Nitrit } \\
\text { Hydroxycobalamin }\end{array}$ & & \\
\hline Irritáns gázok & & N-ACC (foszgén mérgezés esetén) & \\
\hline Szerves oldószerek & & $\begin{array}{l}\text { Béta-receptor blokkoló (ritmuszavar } \\
\text { esetén) } \\
\text { N-ACC (hepatotxicitás kivédésére) }\end{array}$ & \\
\hline \multicolumn{4}{|l|}{ Biotoxinok } \\
\hline Botulinum toxin & Antitoxin & & \\
\hline Viperaméreg & Ellenméreg & Polyvalens immun Fab & \\
\hline Tengeri biomérgek & Ellenméreg, Magnesium (medúzacsípés esetén) & & \\
\hline
\end{tabular}

3. Táblázat: Fontosabb specifikus terápiás lehetôségek toxikológiai beteg peri-arrest ellátásához

\section{Obes betegek}

Minőségi CPR kivitelezése obes betegek esetén számos befolyásoló tényező miatt kihívásokkal teli:

- beteg hozzáférhetősége, transzport

- vaszkuláris út biztosítása

- légútmenedzsment

- a mellkaskompresszió minőségének biztosítása

- vazoaktív anyagok hatékonysága

- a defibrilláció hatékonysága
Lehetőségszerint próbáljuk mega mellkaskompressziót $6 \mathrm{~cm}$-es mélység elérésével végezni. Továbbá az elhízott betegek kemény alapra helyezése időhúzó tényezö, ezért végezhetjük ágyban is a CPR-t. Gyakrabban cseréljük a mellkaskompressziót végző személyt. A defibrilláció hatékonyságának érdekében emeljük az energiaértékek a maximumra. A ballonszelep maszkos lélegeztetés esetén alkalmazzunk 4-kezes technikát és gyakorlott ellátó mielőbb biztosítson emelt szintủ légutat. 


\section{Várandósság}

\subsection{Kritikus állapotú várandós nők esetén kezeljük a periarrest okokat}

Alkalmazzunk döntéstámogató, kritikus állapot koraiazonosítását lehetővé tevő kockázatbecslő rendszereket, amelyek segíthetnek a kritikus állapotú várandós nők korai beazonositásában a strukturált $\mathrm{ABCDE}$ szerinti betegvizsgálati algoritmus alkalmazása során. A vizsgálat kezdeti lépéseként pozícionáljuk a beteget a bal oldalára, a méh manuális eltartásával az aorta/cavalis nyomás elkerülése érdekében. Cél-szaturációs értéknek megfelelő oxigénterápiát alkalmazzunk. Hypovolémia és hypotenzió jelei esetén kezdjünk folyadékterápiát. Mérlegeljük a reverzibilis okok mentén a gyógyszeradás indikációs köreit. Lehetőség szerint mielőbb riasszunk komplex teamet, szülész-nőgyógyásszal, aneszteziológussal, sürgősségi ellátóval, neonatológussal. Keringésmegállás esetén kezeljük a reverzibilis okokat, adjunk tranexámsavat $1 \mathrm{~g}$ i.v dózisban a posztpartum vérzés csökkentésére.

\subsection{Speciális ellátás a várandós nők újraélesztése során}

Várandós nők újraélesztése során komplex teamek felállítása nélkülözhetetlen a sikeres reszuszcitáció érdekében. Amennyiben a periarrest állapotot nem sikerült a komplex kezeléssel megakadályozni, ismerjük fel a keringésmegállást és kezdjük BLS-t. Betöltött 20. gesztációs hetet követően manuálisan pozícionáljuk az uterust balra az aorta/cavalis kompresszió csökkentése érdekében. Optimális döntési szög újraélesztés közben 15-30 fok. Korai szakaszban döntsünk a sürgősségi hysterotomiáról, lehetőség szerint 4 percen belül. Defibrilláció esetén alkalmazzunk öntapadó elektródákat. Korai intubáció indikációja áll fenn a ballonosmaszkos lélegeztetés bizonytalan hatékonysága miatt. Azonosítsuk be és kezeljük a reverzibilis okokat. ALS sikertelenség esetén mérlegeljü̈k helyi protokoll mentén az eCPR alkalmazását.

\section{Légimentés (HEMS)}

A következő alfejezetben röviden összefoglaljuk az ERC 2021-es protokoll(1) légimentésre vonatkozó specialitásait. A légimentő szolgálatok (helikopter, merevszárnyú repülögép) egyrészt a kritikus állapotú betegek/ sérültek speciális háttérrel rendelkező kórházba történő szállítására, a szállítási trauma minimalizálása vehetők igénybe, a transzportidő jelentős csökkentése mellett, másrészt igénybevételüket a kórházak közti szekunder transzportok is indikálják. (27) A legimentésben kivitelezhető beavatkozások mértéke nagyban függ a különböző szintű speciális eszközök meglététől, kompetenciaszintektől, és a rendelkezésre álló tértől (helikopter fülke vs. merevszárnyú repülögép utastér). Ezekből adódóan a protokoll megjegyzi, hogy az ellátók lehetőleg az összes beavatkozást végezzék el a helyszínen, és csak abban az esetben kezdjék meg a transzportot, ha a beteg már a lehetőségekhez mérten leginkább szállítható állapotban van vagy került, minimalizálva ezzel annak az esélyét, hogy transzport közben kevésbé optimális körülmények közt történjen a betegellátás.

\subsection{A repülés megkezdése előtti értékelés fontossága}

A súlyos/kritikus állapotú beteg/sérült szállításának megkezdése előtt, a következőkről kell gondoskodnia az ellátónak:

- minden szükséges felszerelés működőképes

- minden szükséges felszerelés könnyen hozzáférhető

- szükség esetén a megfelelő gyógyszerek elérése és alkalmazása azonnal lehetséges.

A protokoll említi, hogy a transzport megkezdése elött fel kell mérni a beteg repülésre való alkalmasságát, figyelembe véve a repülési idő hosszát a zajló kórfolyamat függvényében. Ugyancsak szem előtt kell tartani a beteg állapotától függően a repülési magasságot, hiszen a változó kabinnyomás hatására az oxigén artériás parciális nyomása $\left(\mathrm{PaO}_{2}\right) 95 \mathrm{Hgmm}$-röl akár $60 \mathrm{Hgmm}$-re is lecsökkenhet.

A légiszállítás stresszt provokáló volta a beteg állapotát negatívan befolyásolhatja, ezért a guideline javasolja a páciens aktuális egészégi állapotának értékelését a következők szerint:

- Történt-e a közelmúltban nagyobb testüreget/zsigert érintő műtét?

- Volt-e a közelmúltban, vagy fennáll-e jelenleg PTX?

- Történt-e koponyasérülés?

- Fennáll-e akut pszichotikus mentális betegség?

- Fennál-e a szülés/koraszülés?

- Fennáll-e akut miokardiális infarktus vagy instabil angina pectoris?

- Volt-e szívműtét a közelmúltban? 
12.2 A beteg állapotában bekövetkező változás értékelhetősége légi transzport közben

A súlyos/kritikus állapotú betegek/sérültek légi transzportja közben az ERC ajánlás alapján fontos a folyamatos monitorizálás végzése. Abban az esetben, ha a beteg spontán keringése megszúnik (asystolia, VF, pnVT), úgy a monitor által jelzett hangalapú figyelmeztetés észrevétele nehézkes lehet a hangos zaj miatt. Tovább nehezíti a felismerést, ha a páciens szedált/relaxált/ altatott állapotban van. A légimentésben ezért nagy hangsúlyt kell fektetni a tudatállapot folyamatos értékelésére, az EKG monitoron látható mintázatban történő változásra, a $\mathrm{SpO}_{2}$ csökkenésére, és a légzés, pulzus hiányának időben való felismerésére. Intubált, lélegeztetett beteg esetén az $\mathrm{EtCO}_{2}$ érték hírtelen csökkenése, vagy a monitoron a görbe elvesztése hívhatja fel a figyelmet az arreszt állapotra.

\subsection{Az ALS módosításai a légimentés egyes eseteiben}

Ha légzés/keringésmegállást tapasztal az ellátó légiszállítás közben, azt azonnal jeleznie kell az egység többi tagja felé. Abban az esetben, ha nem megoldható a strandard CPR végzése, úgy a protokoll javasolja a „fej végi”, „fej feletti” mellkaskompresszió megkezdését. Ha azonban a szük hely (pl: helikopter kabin) lehetetlenné teszi a manuális mellkaskompressziót, úgy javasolt a mechanikus mellkaskompresszáló eszköz alkalmazása (Lucas, AutoPulse). Repülés közben bekövetkezett keringésleállás esetén, ha nem áll rendelkezésre mechanikus mellkaskompresszáló eszköz és/vagy nincs felhelyezve a betegre, azonnal fontolóra kell venni a leszállás eshetőségét, a hatásos $C P R$ megkezdhetősége céljából. Légútbiztosítás szempontjából elsődlegesen szupraglottikus eszköz (SGE) alkalmazását javasolja a protokoll, amennyiben nem volt előtte lélegeztetve a páciens. Ha transzport közben sokkolandó ritmus azonosítható (VF, pnVT), úgy a guideline alapján azonnal 3 egymást követő sokk leadása javasolt. Összességében elmondható, hogy a 2021-es protokoll által javasolt légimentésre irányuló eljárásban érdemi változás nem történt.

\section{Tömeges káresemény}

A tömeges baleseti történés speciális szervezést igénylő káresemény, mivel esetében az egy helyen egészségügyi/orvosi ellátásra szoruló betegek száma meghaladja a rendelkezésre álló erőforrás számát. (28) Kialakulásukért leggyakrabban közlekedési balesetek, természeti katasztrófák, terrorcselekmények okolhatók, de akár kémiai, biológiai, radiológiai vagy nukleáris (KBRN) káresemények miatt is kialakulhatnak. (29)

\subsection{Biztonság}

Az ajánlás egyértelműen meghatározza, hogy tömeges káresemény esetén azonnal azonosítani kell a potenciális veszélyforrásokat, és az ellátáshoz megfelelő mentőerőt szükséges biztosítani. Több potenciális halálos áldozat esetén figyelmeztetni kell a mentőerőket a KBRN eshetőségére. A protokoll kiemeli a biztonság fontosságát, és a következőket fogalmazza meg, mint főbb kockázati tényezők:

- Lövöldözés

- Pokolgép robbanás

- $\mathrm{CO}_{2}$ mérgezés esélye

- Ipari cianidok, egyéb vegyi anyagok jelenléte

A biztonság szempontjából az egyéni (speciális) védőfelszerelések használata kiemelten fontos, még akkor is, ha kutatások bizonyítják, hogy használatuk jelentősen befolyásolhatja az ellátás minőségét, megnövelheti annak időtartamát. (30) (31)

\subsection{Triage}

A megfelelő triage rendszer alkalmazásával osztályozhatók az áldozatok, és meghatározható az ellátás menete az sérültek priorizálása szempontjából. Tömeges káresemény esetén a kompromisszum-medicina elve alapján történik a betegellátás, ahol az ellátók az aránytalanság miatt kezdetben szuboptimális terápiát kényszerülnek alkalmazni. A kórházi felvételkor a protokoll alapján szükséges elvégezni a re-triage-t, ami a beteg további ellátása és az erőforrások allokációja szempontjából releváns. A guideline kiemeli, hogy a következő azonnali, életmentő beavatkozást kell megkezdeni a helyszínen:

- Légutak megnyitása/biztosítása egyszerü légútbiztosító módszerekkel

- Aktív vérzések kontrollálása

- tPTX esetén azonnali mellkasdekompresszió

- antidótumok használata amennyiben elérhető és releváns

- Nem légző gyermek esetén annak lélegeztetése 
A sérült/ellátó aránytalanság miatt a légzés, keringés nélküli felnőttek CPR-e késleltetetten, az aránytalanság rendezőségét követően kezdhetők meg.

\section{Felhasznált irodalom}

1. Lott C, Truhlář A, Alfonzo A, et al. European Resuscitation Council Guidelines 2021: Cardiac arrest in special circumstances. Resuscitation. 2021 Apr 1;161:152-219.

2. Kleber C, Giesecke MT, Lindner T, et al. Requirement for a structured algorithm in cardiac arrest following major trauma: Epidemiology, management errors, and preventability of traumatic deaths in Berlin. Resuscitation. 2014;85(3):405-10.

3. Cera SM, Mostafa G, Sing RF, et al. Physiologic predictors of survival in post-traumatic arrest. Am Surg. 2003;69(2):140-4.

4. Jeffcoach DR, Gallegos JJ, Jesty SA, et al. Use of CPR in hemorrhagic shock, a dog model. J Trauma Acute Care Surg. 2016;81(1):27-33.

5. Leis CC, Hernández CC, Garcia-Ochoa Blanco MJ, et al. Traumatic cardiac arrest: Should advanced life support be initiated? J Trauma Acute Care Surg. 2013;74(2):634-8.

6. Endo A, Kojima M, Hong Z-J, et al. Open-chest versus closed-chest cardiopulmonary resuscitation in trauma patients with signs of life upon hospital arrival: A retrospective multicenter study. Crit Care. 2020;24(1).

7. Spahn DR, Bouillon B, Cerny V, et al. The European guideline on management of major bleeding and coagulopathy following trauma: fifth edition.

8. Guyette FX, Sperry JL, Peitzman AB, et al. Prehospital Blood Product and Crystalloid Resuscitation in the Severely Injured Patient: A Secondary Analysis of the Prehospital Air Medical Plasma Trial. Ann Surg. 2021;273(2):358-64.

9. Frei C, Darocha T, Debaty G, et al. Clinical characteristics and outcomes of witnessed hypothermic cardiac arrest: A systematic review on rescue collapse. Resuscitation. 2019 Apr;137:41-8.

10. Pasquier M, Hugli O, Paal P, et al. Hypothermia outcome prediction after extracorporeal life support for hypothermic cardiac arrest patients: The HOPE score. Resuscitation. 2018 May;126:58-64.
Ahhoz, hogy a tömeges káreseményen hatékonyan és eredményesen tudjanak az ellátók együtt dolgozni, a folyamatos gyakorlás (videó, videójátékok segítségével is), továbbképzés szükséges.

11. Paal P, Rauch S. Indoor accidental hypothermia in the elderly: An emerging lethal entity in the 21 st century. Emerg Med J. 2018;35(11):667-8.

12. Kay JE. Jr in Global Effects of Environmental Pollution. Vol. 3, Geophys. Res. Lett. Springer; 1970.

13. Robine JM, Cheung SLK, Le Roy S, et al. Death toll exceeded 70,000 in Europe during the summer of 2003. Comptes Rendus - Biol. 2008 Feb;331(2):171-8.

14. Lipman GS, Gaudio FG, Eifling KP, et al. Wilderness Medical Society Clinical Practice Guidelines for the Prevention and Treatment of Heat Illness: 2019 Update. Vol. 30, Wilderness and Environmental Medicine. Elsevier Ltd; 2019. p. S33-46.

15. Douma MJ, Aves T, Allan KS, et al. First aid cooling techniques for heat stroke and exertional hyperthermia: A systematic review and meta-analysis. Vol. 148, Resuscitation. Elsevier Ireland Ltd; 2020. p. 173-90.

16. Sampson HA, Muñoz-Furlong A, Campbell RL, et al. Second symposium on the definition and management of anaphylaxis: Summary report - Second National Institute of Allergy and Infectious Disease/Food Allergy and Anaphylaxis Network symposium. In: Journal of Allergy and Clinical Immunology. Mosby; 2006. p. 391-7.

17. Turner PJ, Campbell DE, Motosue MS, et al. Global Trends in Anaphylaxis Epidemiology and Clinical Implications. J Allergy Clin Immunol Pract. 2020 Apr;8(4):1169-76.

18. Singletary EM, Zideman DA, De Buck EDJ, et al. Part 9: First Aid: 2015 international consensus on first aid science with treatment recommendations. Vol. 132, Circulation. 2015. 269-311 p.

19. Anagnostou K, Turner PJ. Myths, facts and controversies in the diagnosis and management of anaphylaxis. Arch Dis Child. 2019;104:83-90.

20. Harper NJN, Cook TM, Garcez T, et al. Anaesthesia, surgery, and life-threatening allergic reactions: management and outcomes in the 6th National Audit Project (NAP6). Br J Anaesth. 2018 Jul;121(1):172-88. 
21. Wallmuller C, Meron G, Kurkciyan I, et al. Causes of in-hospital cardiac arrest and influence on outcome. Resuscitation. 2012 Oct 1;83(10):1206-11.

22. Alfonzo A, Macrury MM, Harrison A, et al. Clinical Practice Guidelines Treatment of Acute Hyperkalaemia in Adults. Ren Assoc [Internet]. 2020;(June). Available from: www.nice.org.uk/accreditation

23. Kardalas E, Paschou SA, Anagnostis P, et al. Hypokalemia: A clinical update [Internet]. Vol. 7, Endocrine Connections. BioScientifica Ltd.; 2018 [cited 2021 Apr 21]. p. R135-46. Available from: https://doi.org/10.1530/EC-18-0109

24. MowryJB, Spyker DA, Cantilena LR, et al.2013 Annual Report of the American Association of Poison Control Centers' National Poison Data System (NPDS): 31st Annual Report. Clin Toxicol [Internet]. 2014 Dec 6 [cited 2021 Apr 21];52(10):1032-283. Available from: http://www.tandfonline.com/doi/full/10.3109/1556 3650.2014 .987397

25. Cole JB, Arens AM, Laes JAR, et al. High dose insulin for beta-blocker and calcium channel-blocker poisoning. Am J Emerg Med. 2018 Oct 1;36(10):1817-24.
26. Graudins A, Lee HM, Druda D. Calcium channel antagonist and beta-blocker overdose: Antidotes and adjunct therapies. Br J Clin Pharmacol. 2016;81(3):453-61.

27. Lyon RJ, Brooke JM, Knowles JD, et al. A study on classification in imbalanced and partially-labelled data streams. Proc - 2013 IEEE Int Conf Syst Man, Cybern SMC 2013. 2013;(2013):1506-11.

28. Griffiths MJD, Mcauley DF, Perkins GD, et al. Guidelines on the management of acute respiratory distress syndrome. BMJ Open Resp Res. 2019;6:420.

29. El Sayed M, Tamim H, Mann NC. Description of procedures performed on patients by emergency medical services during mass casualty incidents in the United States. Am J Emerg Med. 2015 Aug;33(8):1030-6.

30. Nolan JP, Monsieurs KG, L.Bossaert, et al. European Resuscitation Council COVID-19 guidelines executive summary. Resuscitation. 2020 Aug;153:45-55.

31. Lamhaut L, Dagron C, Apriotesei R, et al. Comparison of intravenous and intraosseous access by pre-hospital medical emergency personnel with and without CBRN protective equipment. Resuscitation. 2010 Jan;81(1):65-8. 